\title{
Small-Molecule Modulators of Mitochondrial Channels as Chemotherapeutic Agents
}

\author{
Sofia Parrasia ${ }^{a}$ Andrea Mattarei $^{b} \quad$ Alberto Furlan ${ }^{b}$ Mario Zorattia,c \\ Lucia Biasutto ${ }^{a, c}$ \\ a'Dept. of Biomedical Sciences, University of Padova, Padova, Italy, ${ }^{b}$ Dept. of Pharmaceutical and \\ Pharmacological Sciences, University of Padova, Padova, Italy, 'CNR Neuroscience Institute, Padova, \\ Italy
}

\section{Key Words}

Mitochondrial channels $\bullet$ Cancer $\bullet$ Channel modulators $\bullet$ Mitochondria-targeting

\begin{abstract}
Ion channels residing in the inner (IMM) and outer (OMM) mitochondrial membranes are emerging as noteworthy pharmacological targets in oncology. While these aspects have not been investigated for all of them, a role in cancer growth and/or metastasis and/or drug resistance has been shown at least for the IMM-residing $\mathrm{Ca}^{2+}$ uniporter complex and $\mathrm{K}^{+}-$ selective $\mathrm{mtK}_{\mathrm{v}} 1.3, \mathrm{mtIK}_{\mathrm{Ca}^{\prime}} \mathrm{mtSK}_{\mathrm{ca}_{\mathrm{a}}}$ and $\mathrm{mtTASK}-3$, and for the OMM Voltage-Dependent Anion Channel (mitochondrial porin). A special case is that of the Mitochondrial Permeability Transition Pore, a large pore which forms in the IMM of severely stressed cells, and which may be exploited to precipitate the death of cancerous cells. Here we briefly discuss the oncological relevance of mitochondria and their channels, and summarize the methods that can be adopted to selectively target these intracellular organelles. We then present an updated list of known mitochondrial channels, and review the pharmacology of those with proven relevance for cancer.
\end{abstract}

\section{Introduction}

Targeting mitochondria to antagonize cancer has ceased to be an oncological side-show to become a major play, with the emergence of a whole new field of pharmacology based on so-called "mitocans" [1]. The mitochondria of cancerous cells acquire specific characteristics and functions [2, 3]. Thus, for example, the Krebs' cycle becomes a key provider of biosynthetic intermediates and modulators of enzymes, epigenomic control and thus gene expression [4]. An increased production of reactive oxygen species (ROS) by mitochondria contributes to the rapid and limitless growth phenotype [5], and it also constitutes a cellular

Lucia Biasutto CNR Neuroscience Institute

Viale G. Colombo 3, 35121 Padova, Italy

Tel. +39049 8276054, Fax +39 0498276040, E-Mail lucia.biasutto@cnr.it 


\section{Cellular Physiology Cell Physiol Biochem 2019;53(S1):11-43 \\ \begin{tabular}{ll|l} 
and Biochemistry & Published online: 14 December 2019 & $\begin{array}{l}\text { C } 2019 \text { The Author(s). Published by } \\
\text { Cell Physiol Biochem Press GmbH\&Co. KG }\end{array}$
\end{tabular}}

Achilles' heel, since it brings the threshold for oxidative cell death within reach for redox stress-inducing drugs [6]. Mitochondrial alterations, and/or alterations in pro-apoptotic signaling to mitochondria, make cancer cells resistant to extrinsic apoptosis induction. Mitochondrial fusion/fission dynamics have been related to cancer cell invasiveness and maintenance of "stemness" [7]. The bioenergetic characteristics of cancer stem cells $[8,9]$ point to mitochondrial intervention for their eradication [10]. In summary, the prominence of the mitochondrial role in cancer and the alterations of the mitochondrial characteristics and functions in cancerous cells provide a clear rationale for the "mitocan" approach [1].

Mitochondrial ion channels provide one of the features that can be exploited [1113]. As discussed elsewhere [12,14] (Szabò et al, this Special Issue), alterations in their expression levels are commonplace in cancer. They are of special interest in many cases of chemoresistance [15] and possibly for the elimination of cancer stem cells [16, 17]. An updated list of the channels reported to be present in mitochondria is shown in Table 1. This is an expanding field, and the list will probably become longer and more detailed in the next few years. Obviously, not all these channels are necessarily functioning in all cells, and not all of them have a major role in any given cancer. Those for which evidence of such a role has been provided are identified in Table 1 . Much, actually most, remains to be learned and understood. Some of the mitochondrial channels have been studied in more depth than others in this context. This can be said for example of $\mathrm{mtK}_{\mathrm{v}} 1.3$, which is covered by another contributed paper (Leanza et al., this Special Issue), and of Voltage-Dependent Anion Channel (VDAC)-1. The latter, the mitochondrial porin, serves to show that outer mitochondrial membrane (OMM) channels may be of key importance in this context, laying to rest the vision of the OMM as a passive sieve. Another key point is that while a few of these channels are endemic to mitochondria, several reside in the plasma membrane (PM) and other intracellular membranes as well [11], and this may complicate the pharmacology. The logical move to counteract this difficulty is to engineer the specific accumulation of the drug at mitochondria: non-mitochondrial channels in both normal and cancerous cells will thus

Table 1. Ion channels with mitochondrial location and their involvement in cancer

\begin{tabular}{|c|c|c|c|c|c|}
\hline Channel & Selectivity & Mito location & Link to cancer & Other location(s) & Notes \\
\hline VDAC1 & cations, $\mathrm{Ca}^{2+}$ variable & {$[275,349,350]$} & {$[293,351-354]$} & $\begin{array}{c}\text { Plasma membrane, ER/SR, } \\
\text { endosomes }\end{array}$ & $\begin{array}{c}\text { Flow of small } \\
\text { metabolites is also } \\
\text { allowed }\end{array}$ \\
\hline $\mathrm{K}_{\text {ATP }}$ & cations, $\mathrm{K}^{+}$ & [356] & / & / & \\
\hline $\mathrm{BK} \mathrm{Ca}$ & $\mathrm{Ca}^{2+}, \mathrm{K}^{+}$ & {$[200,357-359]$} & {$[202,203]$} & $\begin{array}{c}\text { Plasma membrane, ER membrane, } \\
\text { nuclear envelope, lysosomal } \\
\text { membrane, Golgi }\end{array}$ & \\
\hline $\mathrm{IK}_{\mathrm{Ca}}$ & $\mathrm{Ca}^{2+}, \mathrm{K}^{+}$ & {$[214,215]$} & {$[211,212,360,361]$} & Plasma membrane & \\
\hline $\mathrm{SK}_{\mathrm{Ca}}$ & $\mathrm{Ca}^{2+}, \mathrm{K}^{+}$ & {$[231,232]$} & [230] & $\begin{array}{l}\text { Plasma membrane, } \\
\text { ER membrane }\end{array}$ & $\begin{array}{c}\text { Neurons, } \\
\text { cardiomyocytes }\end{array}$ \\
\hline TASK-3 & $\mathrm{K}^{+}$ & [246] & {$[246,249]$} & Plasma membrane & \\
\hline MCU & $\mathrm{Ca}^{2+}$ & [362] & {$[108,109]$} & / & \\
\hline Ryr & $\mathrm{Ca}^{2+}$ & [363] & / & $\begin{array}{c}\text { Sarcoplasmic reticulum, nuclear } \\
\text { envelope }\end{array}$ & \\
\hline Kv1.3 & $\mathrm{K}^{+}$ & [371] & {$[151,157,186,372]$} & $\begin{array}{c}\text { Plasma membrane, ER, Golgi, } \\
\text { nuclear envelope }\end{array}$ & \\
\hline Kv1.5 & $\mathrm{K}^{+}$ & [187] & {$[186]$} & Plasma membrane & \\
\hline $\mathrm{K}_{V} 7.4$ & $\mathrm{~K}^{+}$ & [373] & / & & $\begin{array}{c}\text { Auditory neurons, } \\
\text { skeletal muscle }\end{array}$ \\
\hline ROMK2 & $\mathrm{K}^{+}$ & {$[374]$} & / & Plasma membrane & Renal epithelia \\
\hline TRPC3 & $\mathrm{Ca}^{2+}$ & [375] & [376] & Plasma membrane & \\
\hline nAChRs & $\mathrm{Na}^{+}, \mathrm{Ca}^{2+}$ & {$[377-379]$} & {$[380,381]$} & Plasma membrane & \\
\hline ASIC1 & $\mathrm{Na}^{+}$ & [382] & / & Plasma membrane & \\
\hline IMAC & anions & [383] & / & & \\
\hline CLIC4 & $\mathrm{Cl}^{-}$ & {$[335,384,385]$} & {$[347,386]$} & Cytosol, nuclear membrane, ER & $\begin{array}{c}\text { Cardiomyocytes, } \\
\text { keratinocytes }\end{array}$ \\
\hline
\end{tabular}


be largely spared, and this may help limit side-effects. Drug action on mitochondrial targets will on the other hand have a stronger, selective effect in cancer cells. Target specificity is in principle easier to achieve for inner mitochondrial membrane (IMM) residents, because advantage can be taken of the electrical potential and concentration gradients maintained across the IMM but not across the OMM. The issue of drugging a specific component of an intracellular organelle is superimposed on the upstream problem of selective delivery to the cancerous tissue. This latter topic is not covered here (for reviews see, e.g.: [18-21]).

We provide a summary of the strategies and difficulties involved in selectively aiming at mitochondrial targets, then individually discuss the pharmacology of the mitochondrial channels with a recognized role in cancer.

\section{Mitochondrial targeting}

Targeting a drug to mitochondria - or for that matter to any subcellular compartment - can rely on two strategies: a) attaching an "address" moiety to the active principle (Fig. 1) or b) arranging for transportation by a nanostructured targeted carrier. Within the first approach a distinction can be made between molecules in which the targeting moiety is attached permanently and prodrugs based on a labile linker, whose splitting will regenerate the parent active portion. Chemical modification entails new pharmacologically relevant properties which need to be taken into consideration. Moderate lipophilicity and molecular weight are required for an optimal membrane permeation [22].

In most cases mitochondrial targeting relies on the transmembrane potential to drive drugs engineered to carry - stably or temporarily (prodrugs) - a positive charge into the matrix or IMM. Accumulation of membrane-permeant cations into regions at negative electrochemical potential is mandated by the laws of thermodynamics, a principle first applied in this setting by Skulachev's group 50 years ago [23] and later used in any number of biomedical studies (revs., e.g: [24, 25]). In order for the cation to cross biomembranes, in the absence of a specific carrier, the positive charge needs to be delocalized and the molecule as a whole needs to be sufficiently lipophilic. This very often translates into the incorporation

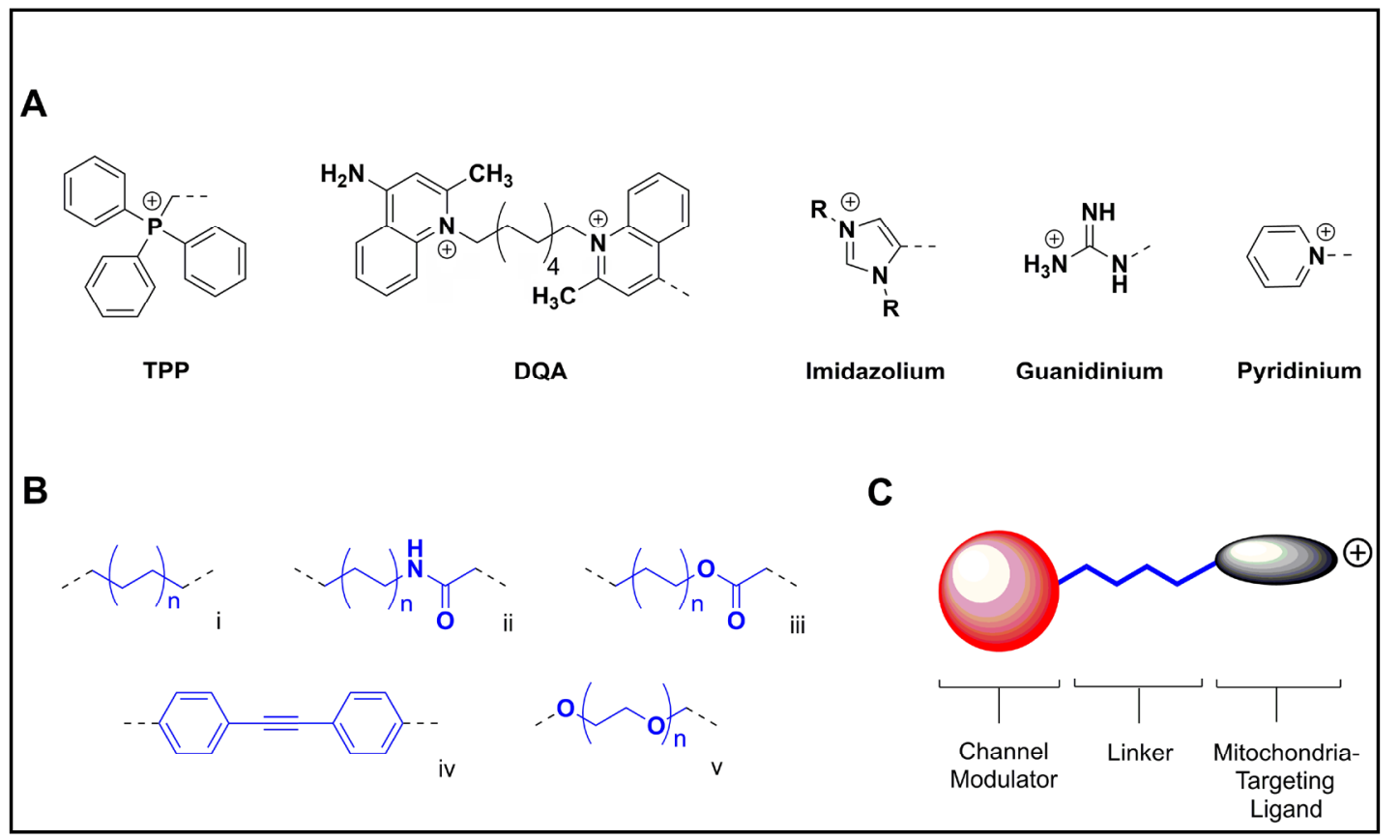

Fig. 1. A) Common mitochondria-targeting ligands; B) examples of linkers between the targeting moiety and the drug; C) typical mitochondria-targeting conjugate scheme. 
into the mitochondriotropic molecule of a triphenylphosphonium (TPP) group connected to the pharmacologically active moiety via a linker (which may contain a "bioreversible" bond system if a prodrug is desired). Besides providing a well-tested, reliable stratagem, using TPP facilitates the chemist's task, because - possible complications aside - it can be easily produced by reacting a good and easy-to-handle nucleophile, triphenylphosphine, with an electrophilic center carrying a good leaving group, such as a iodide or tosylate (p-toluensulfonate). On the down side, any lipophilic group is bound, by definition, to have a significant affinity for biomembranes. The positive charge furthermore favors interactions with negatively charged cell components, such as phospholipid headgroups and DNA. Not to be forgotten, it also determines accumulation into the cytosol, which - while electrically positive in comparison to the mitochondrial matrix - is at a more negative potential than the extracellular space. Unsurprisingly, TPP-containing compounds exhibit extensive binding also to non-mitochondrial structures [26]. Because of this tendency to give pleiotropic interactions, off-targets are a possibility to be considered even more seriously than for drugs in general. In fact, at relatively high (several $\mu \mathrm{M}$ ) concentrations some TPP conjugates seem to cause mitochondrial dysfunction. This has been observed with TPP surfactants [27] but also phenolic derivatives [28] and other seemingly nondescript TPP-comprising molecules [2931]. At least in some cases the disrupting effect appears to be associated with an interaction with Complex I of the respiratory chain and the ensuing upregulation of ROS production [32, 33]. ROS in turn can affect some intracellular channels [34]. However, emphatically, not all TPP-comprising compounds produce such effects (e.g. [28, 29]), and specifically this is not the case of the psoralenic derivatives discussed below. Controls are clearly needed in each case.

These shortcomings of the TPP group prompt consideration of alternative mitochondriatargeting groups, including dequalinium (DQA), imidazolium, guanidinium, pyridinium, rhodamine, and triethylammonium groups [35] (Fig. 1A). DQA is a dicationic lipophilic compound formed by two quinaldinium rings linked by ten methylene groups. It can selfassemble into vesicle-like liposomes referred to as DQAsomes [36], which have been used to deliver chemotherapeutics drugs and genetic material to mitochondria [37]. Imidazolium cations have been used to convey fluorophores to the mitochondria of cultured cells [38], and could be exploited, in principle, to target pharmaceuticals as well. Conjugation of porphyrins with guanidinium/biguanidinium determined a "clean" mitochondrial localization in cultured cells [39]. Both Rhodamine 123 and Rhodamine 19 are mitochondria-targeting moieties because of their delocalized positive charge and ability to cross biomembranes. Rhodamine 19 has been tested in substitution of TPP to form a mitochondriotropic rhodamine 19plastoquinone conjugate [40]. Pyridinium has been used as the targeting group, for example, in compound F16 and its derivatives, which act as anticancer mitochondrial uncouplers [41] and in the rhodocyanine dye MKT-077, a mtHsp70 inhibitor evaluated in an oncological clinical trial $[42,43]$.

Peptides can also be used as mitochondria-targeting devices [24, 44, 45]. These belong to the family of cell-penetrating peptides (CPPs): positively-charged aminoacid sequences capable of entering the cell and, at least in principle, to carry along a "cargo" as well, e.g. in a prodrug (e.g. [45]). Unsurprisingly, the best-performing Mitochondria Penetrating Peptides (MPPs) alternate charged and lipophilic residues [44]. As for TPP-comprising molecules, some of these peptides may act as mitochondria-disrupting agents, with potential direct anti-cancer applications. This "mitotoxic" activity increases with charge and lipophilicity [44]. Analogously, mitochondrial demise may be brought about by peptide-lipid conjugates [46]. In other studies, MPPs have been used to ferry cytotoxic - DNA-damaging - agents to mitochondria (e.g.: $[47,48]$ ). The peptide may be tailored to engage the mitochondrial protein import system. This option has been, perhaps surprisingly, rather neglected so far, with only a few studies aimed at the mitochondrial delivery of DNA $[49,50]$ or supramolecular systems $[51,52]$.

In order to achieve both selective mitochondrial targeting and optimal binding affinity and specificity for the desired mitochondrial ion channel, the position of the targeting 


\section{Cellular Physiology Cell Physiol Biochem 2019;53(S1):11-43 \\ \begin{tabular}{ll|l} 
and Biochemistry $10.33594 / 000000192$ & DO 2019 The Author(s). Published by \\
Published online: 14 December 2019 & Cell Physiol Biochem Press GmbH\&Co. KG
\end{tabular} \\ Parrasia et al.: Drugs vs Mitochondrial Channels in Cancer}

moiety needs to be optimized through structure-activity relationship (SAR) studies. The spacer between the targeting moieties and the pharmacophores can be of various types (Fig. 1B): an alkyl chain with saturated C-C bonds (Fig. 1B, i), or comprise amide (Fig. 1B, ii), ester (Fig. 1B, iii) and disulfide functionalities. Phenylethynyl (Fig. 1B, iv) and polyethylene glycol (Fig. 1B, v) linkers have also been used. Different linkers will provide different chemical and spatial properties to the conjugate, i.e. a phenylethynyl linker is characterized by its rigidity and a polyethylene glycol linker provides higher water solubility. A spacer between the channel modulator and the targeting ligand allows for an optimal recognition.

In the second alternative - using nanocarriers for selective mitochondrial delivery the targeting problem is obviously shifted from the single molecule to the supramolecular structure, but the principles applied remain much the same. This approach may offer a number of advantages: it may incorporate various components acting in synergy to optimize delivery; it makes it unnecessary to modify the active principle, and protects it from metabolic modifications; it may be used to deliver an assortment of "cargos". On the other hand nanocarriers may encounter difficulties in crossing biomembranes, or use complex and "dangerous" processes, such endocytosis, to do so. This may however turn out to be an advantage for the specific delivery to tumor masses through "defects" of vascular epithelia. This field, born more than 20 years ago with Weissig's dequalinium liposomes [36] is blooming (revs.: $[24,53]$ ), although results in in vivo cancer models have yet to meet expectations [54]. The surface of nanovehicles has been decorated with TPP (e.g. [55-57]; the synthesis of TPP-lipid conjugates has been described by [58]) and peptides (e.g. [59, 60]). The possibility of introducing cooperating targeting structures has been taken full advantage of in the development of Multi-Functional Envelope-Type Nano Devices (MENDs) by Harashima's group (rev.s, e.g.: [61]). The various components of these systems act to limit recognition by the reticuloendothelial system, favor uptake into cells and exit from endosomes, and selective delivery to the target compartment. In cultured cells, MENDs can achieve the delivery of small molecules to the mitochondrial matrix [62].

Both strategies - structural modification, packaging - can be used, perhaps in combination, to deliver known or novel channel modulators to mitochondria. This approach has been adopted so far only in a few studies, and the potential for further development is great. We give below a concise overview - limited to matters of oncological interest - of the state of the art.

\section{The Mitochondrial Permeability Transition Pore}

Whether the Mitochondrial Permeability Transition Pore (MPTP; recent revs., e.g.: [6365]) ought to be considered a channel in the same sense as the others mentioned in this review may be a moot point. This is a variable-size (up to very large) pore believed to fulfill physiological roles via transient brief openings, and of major biomedical interest because its full activation leads to mitochondrial depolarization, loss of key soluble matrix components, and cell death. After decades of debates, its molecular identity may now have been settled: the pore is believed to be formed, under the appropriate conditions, by the dimeric $\mathrm{F}_{\mathrm{o}} \mathrm{F}_{1}$ ATP synthase [66, 67]; permissive conditions are a high matrix $\mathrm{Ca}^{2+}$ concentration, and oxidative stress (e.g.: $[68,69]$ ). Given its involvement in major pathologies - e.g. infarct, dystrophy, neurodegeneration - in which it plays the villain, pharmacological research has so far concentrated on inhibitors (e.g. [70]). However, the MPTP is of major relevance also in cancer. Cancerous cells have altered $\mathrm{Ca}^{2+}[71]$ and ROS [72] homeostasis. They adapt to stressful conditions and defend their survival and proliferation by repressing MPT-mediated death [73]. Although this is not always realized by the researchers, facilitating MPTP opening in cancerous cells may therefore underlie - completely or in part - the effects of drugs ranging from traditional medicine preparations [74] to organometallic gold complexes [75, 76]. The connection is the pro-oxidant effect of the drugs, which increases oxidative stress to the point where a critical death-induction threshold is exceeded in already-stressed cancer 
cells, but not - or to a more limited extent - in normal cells. Since the redox sensitivity of $\mathrm{Ca}^{2+}$ channels and transporters of the ER, mitochondria and PM links redox alterations and $\mathrm{Ca}^{2+}$ levels [77], oxidative stress implies $\mathrm{Ca}^{2+}$ stress, the key factors leading to MPTP opening and hence cell death. Anti-cancer strategies based on the upregulation of ROS production are currently receiving much attention [78], with the possible repurposing of several drugs as anti-cancer agents precisely because of their pro-oxidant action (e.g. $[79,80])$. The possibility of overcoming chemoresistance by this approach is an important consideration. The downside is the possibility that redox action may have an undesirable impact on normal cells and organs, for example the heart [81].

It follows that any drug capable of inducing "excess" oxidative stress in cancer cells can be considered as indirectly acting, at least potentially and in part, via the MPTP. Redox stress inducers are plentiful. The already-mentioned metal complexes, including, besides gold compounds, platinum, palladium, copper, silver, ruthenium, tin etc. ones inhibit the thioredoxin reductase (TrxR) system, which is potentiated by cancer cells in order to maintain a degree of redox homeostasis (rev.s, e.g.: [82-85]). Polyphenols, generally considered as anti-oxidants, can actually behave as pro-oxidants and induce cancer cell death by this mechanism (as well as others) (e.g.: $[86,87]$ ). Some, like for example curcumin, myricetin, baicalein, EGCG also are potent TrxR inhibitors [88, 89]. Autoxidation and interaction with the mitochondrial respiratory chain provide further mechanisms of redox stress induction. Redox cyclers such as quinones, paraquat or pyocyanin can act similarly. Redox stress and MPTP activation are also induced by berberine. Methyl jasmonate, a plant hormone, acts likewise and is cytotoxic for cancerous cells while sparing normal ones [90]. The list could go on. The occurrence and relevance of these processes depend on several factors, one of which is the concentration of the active species. Thus, they are expected to be enhanced when a concentrative effect is obtained by coupling to a mitochondria-targeting moiety (see above). Mitochondriotropic derivatives of quercetin, resveratrol, pterostilbene, honokiol, gallic acid, caffeic acid, plastoquinone, menadione and other potentially redox-active compounds have been synthesized and tested, and indeed they show an increased tendency to act as pro-oxidants [24]. The studies with these compounds so far have been limited to in vitro protocols. When applied to cultured cancer cells they do exhibit remarkable cytotoxicity. Their usefulness in in vivo cancer models remains however to be put to test. In vivo models have on the other hand been used to test the efficacy of mitochondriotropic psoralen derivatives, which according to the current mechanistic model act by inducing oxidative stress downstream of the inhibition of a mitochondrial $\mathrm{K}^{+}$channel, and are discussed below.

The MPTP thus serves as the executioner for a number of redox-active compounds with anti-cancer potential. It may be indirectly modulated through the signaling cascades that have been identified to have an impact on its activity [65]. Examples of this approach are provided by hirsutine, an alkaloid, and the synthetic compound GSK1059615. What is lacking - and may not be easy to find, given the molecular nature of the pore is a useful direct activator (for an overview of PT inducers and inhibitors see, e.g., [91]). Polyphosphate, in complex with poly-hydroxybutyrate, has been proposed to act as such [92]. Atractyloside and carboxyatractyloside, two inhibitors of the mitochondrial ADP/ATP exchanger (ANT) stabilizing it in the " $\mathrm{C}$ " conformation, have long been observed to induce IMM permeabilization [93] (while bongkrekate, another inhibitor blocking the carrier in the "M" conformation, antagonizes it). Ebselen, a seleno compound, has been reported to do the same [94]. Logically, the ANT has been proposed to be involved, pointing to the possibility that more than one mechanism of IMM permeabilization may exist [95]. Resminostat, an HDAC inhibitor, triggers the MPT via interaction with Cyclophilin D (a modulatory component of the MPTP) and the ANT [96]. Benzodiazepine 423 binds to the Oligomycin Sensitivity Conferring Protein (OSCP) subunit of the $\mathrm{F}_{0} \mathrm{~F}_{1}$ ATP synthase and facilitates the opening of the MPTP, a finding that was instrumental for the identification of ATP synthase dimers as the molecular substrate of the permeability transition [66, 97]. Various ligands of the OMMlocated peripheral benzodiazepine receptor / Translocator Protein (TSPO) have been found 


\section{Cellular Physiology Cell Physiol Biochem 2019;53(S1):11-43 \\ \begin{tabular}{ll|l} 
and Biochemistry $10.33594 / 000000192$ & DOlished online: 14 December 2019 & $\begin{array}{l}\text { C } 2019 \text { The Author(s). Published by } \\
\text { Cell Physiol Biochem Press GmbH\&Co. KG }\end{array}$
\end{tabular} \\ Parrasia et al.: Drugs vs Mitochondrial Channels in Cancer}

to have analogous effects on mitochondria [98], although the underlying mechanism is at present unclear.

\section{The Mitochondrial Calcium Uniporter Complex}

That mitochondrial $\mathrm{Ca}^{2+}$ handling is of prime importance in cancer follows, if for no other reason, from the role this ion has in precipitating the MPT and cell death (see above). As mentioned, this role belongs to matrix $\mathrm{Ca}^{2+}$. Mitochondrial $\mathrm{Ca}^{2+}$ uptake also modulates (increases) ROS production by the organelles [99] (and is in turn modulated by it; [100]). ROS are an intracellular messenger of the utmost importance in cancer cells, in which, as already mentioned (see above), they are upregulated and contribute to cell proliferation, spreading and metastasis, survival, accumulation of oncogenic mutations, adaptation to hypoxia [101, 102]. Mitochondria contribute to shaping cytosolic $\mathrm{Ca}^{2+}$ signaling $[103,104]$, which, again, is altered in cancer cells and is profoundly involved in such aspects as growth, metastasis, autophagy, drug resistance, escape of immune surveillance, "stemness" [105, 106]. $\mathrm{Ca}^{2+}$ uptake by mitochondria through the ER-mitochondria axis ("ER-mitochondrial $\mathrm{Ca}^{2+}$ fueling") stimulates mitochondrial metabolism thus providing the cancerous cells with an adequate supply of metabolic building. It follows that the mitochondrial machinery for $\mathrm{Ca}^{2+}$ uptake/release is a key character on the oncological stage [107-109]. Its centerpiece is the Mitochondrial Calcium Uniporter Complex (MCUC), comprising various regulatory subunits (rev.s: $[107,110]$ ). Not only the expression level but also the composition of the MCUC have been found to be altered in several cancer types, and these variations appear to be cancer type-specific (revs.: $[107,109]$ ). Post-translational modifications also intervene. It should also be mentioned that the stoichiometric composition of the MCUC varies from organ to organ under normal circumstances as well [111]. Pharmacological interventions aimed at the MCUC therefore ought to be planned case-by-case. Besides the pore-forming MCU, one may target regulatory subunits, or, conceivably, oligomerization - a process favored by oxidative conditions.

Historically, $\mathrm{Ca}^{2+}$ uptake by mitochondria has been blocked by Ruthenium complexes (Ru360) and lanthanides. These Ruthenium complexes appear to be specific blockers of the MCU and can be utilized in studies with cultured cells, including cancer ones but also in vivo (e.g. [112]). Serious drawbacks are the tendency to bind to polysaccharides and difficulty in diffusing across biomembranes. Their use as a possible therapeutic agent in animal cancer models seems to have been limited so far to some studies in the 1970's [113]. A new Ruthenium compound with good permeation and selectivity, Ru265, has been recently reported [114]. Cancer-targeted prodrugs of Ru complexes have been produced and may provide a lead to more useful forms of this type of inhibitors [115]. Other inorganics inhibiting $\mathrm{Ca}^{2+}$ uptake by mitochondria are the lanthanides [116], which would however need much work to be turned into useful drugs.

Among organic compounds, two tetracycline analogues - minocycline and doxocycline - were found to inhibit mitochondrial $\mathrm{Ca}^{2+}$ uptake when applied in the $50 \mu \mathrm{M}$ range, protecting rat hepatocytes from chemical hypoxia-induced death [117]. These antibiotics have shown activity against various cancers (e.g. [118]) as well as for several other conditions. DS16570511 has been identified in a large high-throughput screening [119]. This is a membrane-permeant MCU inhibitor, effective in the $\mu \mathrm{M}$ range. It appears however to have as yet unidentified mitochondrial off-targets [120]. We are unaware of any tests in cancer models so far. The thiourea derivative KB-R7943, an inhibitor of the $\mathrm{PM} \mathrm{Na} / \mathrm{Ca}^{2+}$ exchanger 1, has also been reported to inhibit mitochondrial $\mathrm{Ca}^{2+}$ uptake ( $\mu \mathrm{M}$ range) [121], but whether this reflects a direct effect on the MCUC is unclear, since this drug also has mitochondrial off-targets [122]. Mitoxantrone (a topoisomerase inhibitor with oncological applications) has also emerged as an MCUC inhibitor $\left(\mathrm{IC}_{50}\right.$ in the $\mu \mathrm{M}$ range) from a screening study [123]. Another anticancer drug, proteasome inhibitor Bortezomib, stimulates instead mitochondrial $\mathrm{Ca}^{2+}$ uptake in a Ru360-sensitive manner, and this may contribute to its anti- 


\section{Cellular Physiology Cell Physiol Biochem 2019;53(S1):11-43 \\ \begin{tabular}{ll|l} 
and Biochemistry & $\begin{array}{l}\text { DOl: } 10.33594 / 000000192 \\
\text { Published online: } 14 \text { December } 2019\end{array}$ & $\begin{array}{l}\text { C } 2019 \text { The Author(s). Published by } \\
\text { Cell Physiol Biochem Press GmbH\&Co. KG }\end{array}$
\end{tabular}}

cancer effects [124]. Polyamines, e.g. spermine, also stimulate $\mathrm{Ca}^{2+}$ uptake by mitochondria [125], a finding that may be worth scrutinizing now that the MCUC has been molecularly defined. Aminoglucoside antibiotics also can activate [125]. Activation of the MCUC has also been proposed as the mechanism of anti-cancer action of AG311 [126], which however seems more likely to act by inhibiting complex I of the respiratory chain [127]. An analogous suggestion has been made for Necrox-5 [128], but also in this case subsequent reports point to other targets $[129,130]$. Several plant flavonoids upregulate mitochondrial $\mathrm{Ca}^{2+}$ uptake in vitro [131]. The most effective among those tested was kaempferol, which nearly doubled the rate of mito-aequorin response increase at $1 \mu \mathrm{M}$ in HeLa cells [131].

With the exceptions of Ru360, which has been shown to bind to the aspartate "ring" at the mouth of the MCU channel [132], of Ru265, which involves MCU Cys97 [114] and of oxidative stress, which leads to glutathionylation of Cys 97 and formation of higher oligomers [133], the mechanisms of action of these various compounds remain to be explored.

The MCU complex would be fully expected to undergo regulation by cellular signaling cascades (rev.: [133]). Mitochondrial $\mathrm{Ca}^{2+}$ uptake has been reported to be modulated downstream of p38 MAPK, PKC, PKD, CaMK-II $[134,135]$ but how this comes about needs to be investigated further (see, e.g., [136]). In summary, the pharmacology of the MCUC is still fairly primitive - not surprisingly since the system has been first identified only about 9 years ago $[137,138]$ - but offers excellent perspectives for development and applications, and certainly not only in oncology.

\section{Mitochondrial $\mathrm{K}_{\mathrm{v}}$ channels}

$\mathrm{K}^{+}$is the most abundant cation in both cytosol and mitochondrial matrix; it is used by mitochondria to control volume and some functions [139]; $\mathrm{K}^{+}$channels are the most diversified superfamily of ion channels in nature [140]. It is not surprising therefore that several representatives of the class are present, besides other cell membranes, in the IMM (see Table 1; [141]). The processes involved in regulating the distribution of multiplelocation channels are now beginning to be understood [142]. And given the pervasive roles of ion channels, in general, in cell life, it is also not surprising that altered expression profiles / functions are often found in cancer (e.g.: $[3,14]$; for $\mathrm{K}^{+}$channels: [143]) and may concern ion-conducting but also regulatory subunits [144]. The intersection of these concepts makes it likely that some mitochondrial channels are relevant for cancer, and this is indeed the case (see Table $1 ;[12,13]$ ). Again, this is work in progress, and it may well be that in the future an oncological relevance may emerge for some mitochondrial channels not currently known to have one, and therefore not discussed here.

So far, mitochondrial $\mathrm{K}_{\mathrm{v}}$ channels have been used to precipitate cancerous cell death downstream of their inhibition (see below). It may be considered, however, that an alternative way to reach the same goal may be via their activation by $\mathrm{K}^{+}$channel openers. If sustained, so as to overwhelm the counteracting electroneutral $\mathrm{K} / \mathrm{H}$ exchange, and if the transmembrane electrical potential were maintained, to an extent, by the organelles, activation would be expected to lead to $\mathrm{K}^{+}$influx into the matrix, swelling, and, eventually, OMM rupture and cytochrome c release. As far as we know, this approach has not yet been considered.

$K_{v} 1.3$

$\mathrm{K}_{\mathrm{v}} 1.3$ is likely to be the mitochondrial $\mathrm{K}^{+}$channel to which the most attention has been paid in an oncological context. Its expression and functions in cell life and death are covered in detail in another review of this Special Issue (Leanza et al) and elsewhere [13]. We therefore provide here only a summary.

PM $\mathrm{K}_{\mathrm{v}} 1.3$ is well known to be the target of peptide toxins which block it due to the interaction of a lysine residue with the "ring" of negative charges formed by four aspartate residues in the channel vestibule $[145,146]$. This inhibition can block cell proliferation, and since $\mathrm{PM} \mathrm{K}_{\mathrm{v}} 1.3$ is particularly crucial for lymphocytes, it offers hope for the treatment 


\section{Cellular Physiology Cell Physiol Biochem 2019;53(S1):11-43 \\ \begin{tabular}{ll|l} 
and Biochemistry & $\begin{array}{l}\text { DOI: } 10.33594 / 000000192 \\
\text { Published online: } 14 \text { December } 2019\end{array}$ & $\begin{array}{l}\text { C } 2019 \text { The Author(s). Published by } \\
\text { Cell Physiol Biochem Press GmbH\&Co. KG }\end{array}$
\end{tabular}}

of autoimmune disorders [146]. However, these toxins do not enter cells. IMM $\mathrm{K}_{\mathrm{v}} 1.3$ can likewise be blocked by Lys128 of pro-apoptotic protein Bax following incorporation of the latter into the OMM [147]. Hyperpolarization, ROS production, cytochrome c release and apoptosis follow. These findings suggested that pharmacological inhibition of IMM $\mathrm{K}_{\mathrm{v}} 1.3$ might well produce the same outcome. Wulff, Chandy and coworkers had developed a family of membrane-permeant $\mathrm{K}_{\mathrm{v}}$ inhibitors - including Psora- 4 and its derivative PAP- 1 - based on the psoralenic (furocoumarinic) ring system [148]. These drugs probably act by inserting "sidewise" into the ion-conducting pore with their coumarinic moieties [149]. Clofazimine, an antimycobacterial drug, was also found to be a permeant $\mathrm{K}_{\mathrm{v}} 1.3$ inhibitor [150]. The compounds proved to have some efficacy against various cancerous cells in vitro, in in vivo models of melanoma and pancreatic ductal adenocarcinoma (PDAC) and against B cells from the blood of chronic lymphocytic leukemia (CLL) patients [151-153]. Mitochondriotropic PAP-1 derivatives PAPTP and PCARBTP (a carbamate prodrug) were produced and tested with the goal of improving efficacy and target specificity [154]. The strategy proved successful, achieving important reductions of tumor mass in murine models of melanoma and PDAC and eliminating a very high fraction of ex vivo human CLL cells and of various cultured cell lines. Importantly, they were essentially without effect on healthy tissues. Despite killing glioma cells in vitro, they were however unable to antagonize the tumor in vivo, because they were excluded from the central nervous system by the blood-brain barrier (BBB) [155]. A similar cytotoxicity was exerted by PCTP, a prodrug analogous to PCARBTP but comprising a carbonate group, rather than a carbamate, as labile bond system [156]. The activity of these compounds is sensitive to structural details. Thus, shortening the linker between the furocoumarin system and the "driving" triphenylphosphonium group resulted in a compound (P5TP) with only about the same efficacy as the parent, non-mitochondriotropic PAP-1 [156]. At low doses $(<1 \mu \mathrm{M})$, they may activate pro-survival pathways (Bergermann et al., this Special Issue), thus acting in "hormetic" fashion, or alter the cell cycle [157]. Both effects have been tentatively attributed to the induction of a mild oxidative stress.

Much work has been directed towards the discovery of $\mathrm{K}_{\mathrm{v}} 1.3$ inhibitors because of the role of this channel in inflammatory and autoimmune disorders [158, 159]. A number of natural and synthetic compounds have been found to inhibit $P M K_{v} 1.3$, and might serve as leads for mitochondria-targeted new drugs. These include other psoralen derivatives [160], and the prenylated flavonoids xanthohumol, isoxanthohumol and 6- and 8-prenylnaringenin $\left(\mathrm{EC}_{50}\right.$ in the 3-8 $\mu \mathrm{M}$ range) $[161,162]$. Some derivatives of khellinone inhibited with $\mathrm{K}_{\mathrm{d}}<1$ $\mu \mathrm{M}$ [163-165]. Diphenylphosphine oxide inhibited the channel with an $\mathrm{IC}_{50}$ of $\sim 3 \mu \mathrm{M}$ [166]. Sibutramine (a discontinued appetite suppressant), did the same with $\mathrm{IC}_{50} \sim 3.7 \mu \mathrm{M}$ [167]. Less potent were trifluoperazine, thioridazine, tamoxifen [168], acacetin, chrysin [162, 169], genistein [170], resveratrol [171], simple derivatives of naringenin and piceatannol [172], $18 \beta$-glycyrrhetinic acid [173], lovastatin [174] and other statins [175], verapamil, diltiazem [176]. Derivatives of correolide, a pentacyclic natural compound, have been the object of a SAR study [177]. Patent applications seek to protect whole classes of synthetic $\mathrm{K}_{\mathrm{v}} 1.3$ blockers, based on an amide [178] or an oxazolidinedione [179] core.

Interestingly, $\mathrm{PM} \mathrm{K}_{\mathrm{v}} 1.3$ is inhibited downstream of ceramide production by acid sphingomyelinase (ASM) [180]. Localization of the channel in lipid rafts is involved in this phenomenon [181]. Ceramide [182] and ASM [183] are present in the mitochondria (at least those of some cells under stressful circumstances), and affect processes of the IMM [184, 185].

$K_{V} 1.5$

$\mathrm{K}_{\mathrm{v}} 1.5$ is a first-degree cousin of $\mathrm{K}_{\mathrm{v}} 1.3$, with which it forms heterotetramers. Its expression appears to be altered in several cancers, and to be involved - analogously to $\mathrm{K}_{\mathrm{v}} 1.3$ - in cell proliferation and metastasis [186]. PAP-1 (see above) was selected among a group of psoralen derivatives because of its (rather modest) selectivity for $\mathrm{K}_{\mathrm{v}} 1.3$ over $\mathrm{K}_{\mathrm{v}} 1.5 . \mathrm{K}_{\mathrm{v}} 1.5$ is present in the IMM of macrophages [187], but a mitochondrial localization has not been reported for other cell types. 


\section{Cellular Physiology Cell Physiol Biochem 2019;53(S1):11-43 \\ \begin{tabular}{ll|l} 
and Biochemistry & $\begin{array}{l}\text { DOI: 10.33594/000000192 } \\
\text { Published online: } 14 \text { December } 2019\end{array}$ & $\begin{array}{l}\text { C } 2019 \text { The Author(s). Published by } \\
\text { Cell Physiol Biochem Press GmbH\&Co. KG }\end{array}$
\end{tabular} \\ Parrasia et al.: Drugs vs Mitochondrial Channels in Cancer}

Especially because of its involvement in cardiac function, $\mathrm{K}_{\mathrm{v}} 1.5$ has been the focus of a considerable pharmacological research effort (e.g. [188]). Among the molecules identified as inhibitors are ortho,ortho-disubstituted bisaryl compounds [189], anthranilic amides [190], pyrazolodihydropyrimidine derivatives [191], S0100176 [192], AVE0118 [193], the phosphatidylinositol 3-kinase inhibitor LY294002 [194], verapamil [195], the anesthetic propofol [196], the lipoxygenase inhibitors cinnamyl-3, 4-dihydroxy-alpha-cyanocinnamate and nordihydroguaiaretic acid [197], diphenylphosphine oxide [198]. At least some of these inhibitors act also on $\mathrm{K}_{\mathrm{v}} 1.3$. The structural similarity among voltage-dependent $\mathrm{K}^{+}$channels clearly makes selective targeting difficult.

\section{Mitochondrial $\mathrm{K}_{\mathrm{Ca}}$ channels}

$\mathrm{Ca}^{2+}$-activated $\mathrm{K}^{+}$channels are present in the IMM of several cell types, including some cancer lines (Table 1; $[11,13,141,199,200])$. They are believed to participate in the regulation of trans-IMM potential, ROS production and $\mathrm{Ca}^{2+}$ homeostasis. According to their conductance, they are named "Big" (BK $\mathrm{Ca}^{\prime}$ a.k.a. $\left.\mathrm{K}_{\mathrm{Ca}} 1.1\right)$, "Intermediate" $\left(\mathrm{IK}_{\mathrm{Ca}^{\prime}}\right.$ a.k.a. $\left.\mathrm{K}_{\mathrm{Ca}} 3.1\right)$ and "Small" ( $\mathrm{SK}_{\mathrm{Ca}}$ a.k.a. $\mathrm{K}_{\mathrm{Ca}}$ 2.1-3). $\mathrm{mbK}_{\mathrm{Ca}}[200]$ and $\mathrm{mtSK}_{\mathrm{Ca}}$ (e.g [201].) have been much studied because of their role in cardiac ischemic preconditioning. Less attention has been paid to their possible role in cancer.

$B K_{C a}$

$\mathrm{mtBK}_{\mathrm{Ca}}$ is present in human LN229 glioma and U-87 MG astrocytoma cell lines. CGS7184, a $\mathrm{BK}_{\mathrm{Ca}}$ channel opener, induced mitochondrial depolarization and death of these cells, but the effect seems actually to involve $\mathrm{Ca}^{2+}$ release from the ER and to be independent of $\mathrm{mtBK}_{\mathrm{Ca}}$ opening [202, 203]. Ophiobolin A, a fungal metabolite, is instead a (weak; $\mathrm{IC}_{50} \sim 10 \mu \mathrm{M}$ ) $\mathrm{BK}_{\mathrm{Ca}}$ channel inhibitor, and it also induced death of a cancer (glioblastoma) line [204]. The correlation between the two effects would however need strengthening also in this case.

Besides the compounds just mentioned, many other small molecule $\mathrm{BK}_{\mathrm{Ca}}$ agonists have been identified or synthesized. For detailed reviews please see [205, 206]. These compounds are not, in general, either very powerful (typically they act in the several- $\mu \mathrm{M}$ range) or specific. One of the most powerful may be the triterpenoid glycoside dehydrosaponin, which reportedly acted (unfortunately from the intracellular side) at concentrations as low as 10 nM in planar bilayer experiments [207].

Selective antagonists of $\mathrm{BK}_{\mathrm{Ca}}$ have also been sought, without much luck. For a review please see [208]. Most of the compounds identified - which include, e.g., paxilline, verapamil, quinine, clotrimazole - act also on other $\mathrm{K}^{+}$channels, in particular $\mathrm{IK}_{\mathrm{Ca}}$. A possibly selective one is Penitrem A [209], which acts via subunit $\beta 1$. It is one of a set of indole diterpene alkaloids produced by Penicillium sp., reported to have anti-proliferative and anti-invasive properties against various cancers. Penitrems are however known to act also via the $\mathrm{Wnt} / \beta$ catenin pathway [210].

\section{$I K_{C a}$}

The role of $\mathrm{IK}_{\mathrm{Ca}}$ in cancer is, instead, well supported. The channel is involved with cell migration, proliferation, and invasion, and it has been studied in particular in the context of cancers of the pancreas and breast and gliomas (revs.: [211, 212]). It may furthermore confer radioresistance [213]. The mitochondrial population has been discovered in cancer cell lines $[214,215] . \mathrm{IK}_{\mathrm{Ca}}$ has been found to regulate oxidative phosphorylation in some PDAC cell lines [216], and treatment with a membrane-permeant inhibitor (TRAM-34) sensitized melanoma cells to TRAIL-induced apoptosis [217] and reduced the proliferation rate in a murine breast cancer model [218].

Mitochondria-targeted $\mathrm{IK}_{\mathrm{Ca}}$ inhibitors have not yet been developed. A few membranepermeant inhibitors exist which might serve as leads. One difficulty is the tendency of $\mathrm{K}^{+}$ channel modulators to act on more than one member of the superfamily, a problem due 


\section{Cellular Physiology Cell Physiol Biochem 2019;53(S1):11-43 \\ \begin{tabular}{ll|l} 
and Biochemistry & $\begin{array}{l}\text { DOI: 10.33594/000000192 } \\
\text { Published online: } 14 \text { December } 2019\end{array}$ & $\begin{array}{l}\text { C } 2019 \text { The Author(s). Published by } \\
\text { Cell Physiol Biochem Press GmbH\&Co. KG }\end{array}$
\end{tabular} \\ Parrasia et al.: Drugs vs Mitochondrial Channels in Cancer}

to the intrinsic similarity of these channels. The most hopeful for $\mathrm{mtIK}_{\mathrm{Ca}}$ may well be the tetrarylmethane inhibitors TRAM-34, considered to be selective for $\operatorname{IK}_{\mathrm{Ca}}[219,220]$ and clotrimazole (an antimycotic) [221], both of which inhibit the mitochondrial population in cultured cells [214], and activator 1-EBIO [222]. Several other activators [223] are available as lead compounds. Activators generally have low selectivity, acting on small- as well as intermediate-conductance $\mathrm{K}_{\mathrm{Ca}}$ channels as well as on other channels. However, a SAR study of the benzothiazole pharmacophore of SKA-31 has led to significantly $\mathrm{IK}_{\mathrm{Ca}}$-selective compounds [224]. Among inhibitors, some natural products, e.g. caffeic acid, are also rather weak and unselective [225]. Some synthetic dibenzoates worked in the nM range, but did not distinguish between $\mathrm{IK}_{\mathrm{Ca}}$ and $\mathrm{SK}_{\mathrm{Ca}}$ 's [226]. However TRAM-34, Senicapoc (ICA-17043), NS6180 and a derivative of nifedipine have nM-range potency as well as good selectivity $[223,227]$, and may be the first-choice candidates for elaborations. Dequalinium-related UCL1407, UCL1440, UCL1438 had $\mathrm{IC}_{50}$ values in the $\sim 1 \mu \mathrm{M}$ range [228]. The peptide toxin with the best combination of selectivity and potency for $\mathrm{IK}_{\mathrm{Ca}}$ is maurotoxin [229].

It may well happen - it remains to be investigated in depth - that the mitochondria of a given cancer type might harbour only one or few types of $\mathrm{K}^{+}$channels. Thus, for example, that of $\mathrm{IK}_{\mathrm{Ca}}$ was the only significant activity by $\mathrm{K}^{+}$channels we observed in HCT116 mitochondria [214]. Thus, a mitochondriotropic compound may achieve a sort of "topological selectivity" despite having itself an intrinsically low ability to distinguish among $\mathrm{K}^{+}$channels.

$S K_{C a}$

A role of small-conductance $\mathrm{Ca}^{2+}$-activated $\mathrm{K}^{+}$channels $\left(\mathrm{SK}_{\mathrm{Ca}} 2.1-3\right)$ in cancer has been documented mainly for SK3 (SK ${ }_{\mathrm{Ca}} 2.3$ ) [230]. SK channels are present in the IMM of neurons [231] and of cardiomyocytes [232], where they influence transmembrane potential and respiration and have a protective role. Their possible involvement in cancer cell physiology has not - to our knowledge - been studied, but that their modulation may have (an) effect(s) is a distinct possibility.

The pharmacology of these channels [223] overlaps that of the other $\mathrm{K}_{\mathrm{Ca}}$ channels to a considerable extent. Activators NS309, SKA-31, 1-EBIO/DCEB, SKS-11, SKS-14 [233] are shared with $\mathrm{IK}_{\mathrm{Ca}}$. CyPPA activates instead rather specifically on SK2 and SK3 [234], but also modulates the $\beta$-catenin/GSK3 $\beta$ pathway [235]. Antagonists include NS8593 [201], which however acts on quite distinct channels as well [236]. More SK-selective selective blockers are the small neurotoxin apamin - which was instrumental in the characterization of SK channels themselves [237], but also blocks $\mathrm{K}_{\mathrm{v}} 1.3$ with an $\mathrm{IC}_{50}$ of $13 \mathrm{nM}$ [238] - BBP [239], UCL1684 [228]. SK3 is also inhibited by edelfosine, an ether-linked phospholipid with anticancer properties [240].

\section{TASK}

TASK-3 (Twik-related acid-sensitive $\mathrm{K}^{+}$channel 3; KCNK9; $\mathrm{K}_{2 \mathrm{p}} 9.1$ ) is a member of the two-pore $\mathrm{K}^{+}$channel $\left(\mathrm{K}_{2 \mathrm{P}}\right)$ family. PM TASK channels are involved - with other members of the $\mathrm{K}_{2 \mathrm{P}}$ group - in the conduction of a "background" or "leak" $\mathrm{K}^{+}$current (and hence in setting membrane potential). It has a large role in $\mathrm{O}_{2}$ (respiration) and $\mathrm{pH}$ sensing, apoptosis, the sleep-wake cycle, anesthesia, pain signaling, and various other functions (revs on $\mathrm{K}_{2 \mathrm{P}}$ channels: [241, 242]). It is well known to form heteromeric channels at least with TASK1 , with which it shares about $50 \%$ of the sequence, and TWIK-1. Since it's "designed" to control membrane potential, TASK-3 is strongly expressed in the nervous and cardiovascular systems, but it has been found to be upregulated in several cancer types (e.g.: $[243,244]$ ) and it is recognized to have a role in tumorigenesis [245]. The existence of a mitochondrial population has been known for more than 10 years [246, 247], and suppression of TASK3 expression has deleterious consequences for mitochondria and (cancerous) cells [248, 249]. These observations suggest that mitochondrial TASK-3 may be a target of oncological relevance. 


\section{Cellular Physiology Cell Physiol Biochem 2019;53(S1):11-43

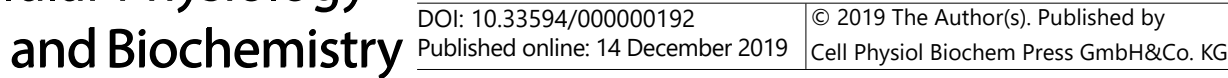 \\ Parrasia et al.: Drugs vs Mitochondrial Channels in Cancer}

TASK channels (and in general $\mathrm{K}_{2 \mathrm{P}}$ channels) however are not the easiest of pharmacological targets (for recent reviews: [250, 251]). Selectivity in particular has turned out to be a problem (a common one for small-molecule $\mathrm{K}^{+}$channel inhibitors). Inhibitors have been sought especially for use as respiratory stimulants. The channel changes its selectivity (i.e., $\mathrm{K}^{+}$transport is inhibited) upon extracellular acidification [252], it is blocked by $\mathrm{Zn}^{2+}$ (which has no effect on TASK-1 and -2) [253], Ruthenium Red [254, 255], by high concentrations $(\sim 10 \mu \mathrm{M})$ of anandamide (which at lower concentrations is selective for TASK1) [256] and by a host of other molecules acting in the tens-of- $\mu \mathrm{M}$ units (or higher) range (tabulated in [250]). TASK-3 is a target of anesthetics [257] and breathing stimulants [258]. One of the latter is Doxapram, which actually selects TASK- $1\left(\mathrm{IC}_{50} \sim 0.4 \mu \mathrm{M}\right)$ over TASK-3 $\left(\mathrm{IC}_{50}\right.$ $\sim 37 \mu \mathrm{M}$ ) or hybrid TASK-1/3 channels ( IC $_{50} \sim 9 \mu \mathrm{M}$ ) in mouse, whereas it is about equipotent vs. TASK- 1 and TASK-3 in human cells ( IC $_{50} \sim 4$ and $\sim 2.5 \mu \mathrm{M}$, respectively) [259, 260]. Among relatively weak inhibitors one may mention molecules derived from dihydropyrrolo [2, 1-a] isoquinoline [261]. Physiologically, the channel can be inhibited downstream of G proteincoupled receptors (GPCRs) acting via phospholipase $\mathrm{C}$ and diacylglycerol, the ultimate modulator [262].

Well-performing antagonists have been identified by SAR studies of series of compounds based on the THPP (5, 6,7, 8 tetrahydropyrido [4, 3-d]pyrimidine) scaffold [263-265]. The most poweful of these derivatives (PK-THPP) exhibited an $\mathrm{IC}_{50}$ of 10-35 nM vs. TASK-3, and little discrimination between TASK-1 and TASK-3 [258, 263]. A1899, is also a selective TASK1 inhibitor. It acts in the nM range, blocking also TASK-3 at approximately 10 -fold higher concentrations [266]. These compounds probably share a binding site inside the pore, reached through "fenestrations" in the channel structure [258, 266, 267]. Flaherty and coworkers [268] have developed another series of powerful inhibitors, based on the 1, 3-bisamide structure. These drugs actually preferentially inhibit TASK-1, which may not be very relevant if the target is mitochondrial TASK(s). The most active towards TASK- 3 showed an $\mathrm{IC}_{50}$ of $38 \mathrm{nM}$ in patch-clamp assays. The thiotriazole ML308, developed by the same group, worked with an $\mathrm{IC}_{50}$ of $\sim 0.4 \mu \mathrm{M}$, and a $>50$-fold selectivity for TASK-3 over TASK-1 [269]. Two small-molecule activators have also been identified: NPBA [270] and terbinafine and analogs [271]. In patch-clamp experiments, NPBA increased TASK-3 current with an $\mathrm{EC}_{50}$ of $6.7 \mu \mathrm{M}$ (but the current was increased up to 6-fold at $10 \mu \mathrm{M}$ ). The allilamine terbinafine, a commercial antifungal medication, acts in the single-digit $\mu \mathrm{M}$ range. Schewe et al [272]. have recently described negatively charged activators (e.g. BL-1249) acting on multiple $\mathrm{K}_{2 \mathrm{P}}$ channels, but TASKs are not mentioned in the paper.

\section{VDAC}

VDAC1

Long-studied VDAC1, or porin (revs.: [141, 273-275]), is a predominantly mitochondrial outer membrane protein, although its presence has been reported also in the ER/SR [276], endosomes [277] and PM [278-280]. From a pharmacological point of view, the challenge in this case may be not so much to selectively hit the mitochondrial population, as to spare the others. VDAC1 is by now well understood to exert control functions in the transport of $\mathrm{Ca}^{2+}$ [281], ATP [282], other metabolites [283], lipids [284] and (at least in yeast) precursors of mitochondrial proteins [285]. Its status thus impacts respiration and cellular ATP levels. It is furthermore at the center of a network of interactions - mediated mainly by the N-terminal - reaching up to 150 partners at a recent count [286]. It has been proposed to be heavily involved in apoptosis $[287,288]$. It comes as no surprise that such a pivotal protein plays a major role in cancer (revs.: [274, 289-293]). In this context, two interactions of major relevance are those with Hexokinase (HK) [294, 295] and tubulin [296, 297] (rev.: [298, 299]). Both are understood to contribute to the "Warburg phenotype" of cancerous cells and to repress apoptosis. Disrupting these interactions is therefore a strategy worth considering. In the former case, methyl jasmonate, a plant hormone, has been found to do the job, but 


\section{Cellular Physiology Cell Physiol Biochem 2019;53(S1):11-43 \\ \begin{tabular}{ll|l} 
and Biochemistry $10.33594 / 000000192$ & DOlished online: 14 December 2019 & $\begin{array}{l}\text { C } 2019 \text { The Author(s). Published by } \\
\text { Cell Physiol Biochem Press GmbH\&Co. KG }\end{array}$
\end{tabular} \\ Parrasia et al.: Drugs vs Mitochondrial Channels in Cancer}

only at mM concentrations [300]. A more efficient approach was based on cell-penetrating peptides copying sequences of the VDAC N-terminal and competing with VDAC itself for binding of HK and possibly other proteins [301-303]. An analogous approach targeted VDAC-Bcl2/Bcl-xL interactions [302, 303]. The peptide agents were remarkably successful also in in vivo models.

A long list of small molecules has been found to act on VDAC reducing its conductance for ions and favoring apoptosis when supplied to cells. These include avicins - a family of plant stress metabolites [304], aspirin - which also induces hexokinase detachment from VDAC [305], erastin and erastin-like compounds - which interfere with tubulin binding [306, 307], Fluoxetine (Prozac) [308], Oblimersen (G3139) - a phosphorothioate [309]. Anion transport inhibitors such as DIDS and SITS interact with VDAC and have been reported to inhibit oligomerization and thus antagonize apoptosis [310]. These agents may all act through other pathways as well, and further investigations are needed. For example, DIDS was found to directly inhibit caspase-3, -8 and -9 activity in HeLa cell lysates [311].

\section{VDAC2 and 3}

While VDAC1 is the most studied and best known of mitochondrial porins, two others exist. They are relatively minor: in HeLa cells for example VDAC2 expression is about $1 / 10$, and VDAC3's about 1/100, of VDAC1 [312]. Whether they form channels has been in doubt for a long time, and whether this is their main function is still an open question (e.g. [313]). In any case, purified VDAC2 can form large pores resembling those of VDAC1 [314, 315], while VDAC3 can yield mostly smaller conductances under reducing conditions [316]. The significance of these proteins in cell life and cancer seems to derive mainly from some specific functions (e.g. [293, 317, 318]), and in particular from their interactome [319]. Thus, in 2003 VDAC2 was found to bind Bak, preventing its oligomerization [320], an interaction confirmed in various subsequent studies (e.g.: [321, 322]). Indeed, WEHI-9625, a newly discovered tricyclic sulfone which binds VDAC2, prevented Bak-driven apoptosis [323]. However VDAC2 seems to play an opposite, pro-apoptotic role in Bax-mediated apoptosis [324, 325]. The porin reportedly forms with Bax and Bak complexes involving different domains. Deletion of VDAC2 impaired the association of Bax and Bak with mitochondria, and inhibited Bax (but not Bak) function and cell killing by anti-cancer drugs acting via Bax (Etoposide, Venetoclax, BH3-mimetics) [325]. VDAC2 can also bind the mitochondria targeting domain of pro-death Noxa, and a peptide mimicking this domain has been reported to induce the mitochondrial permeability transition and necrotic cell death [326]. It has also been reported to provide the docking site for GSK-3 $\beta$, an MPTP-activating kinase [327]. VDAC2 seems also to be coresponsible for apoptosis induction by ceramide, which it binds at a site present also in VDAC1. Deletion or mutation of this binding site in VDAC2, but not in VDAC1, made colon cancer cells resistant to ceramide-induced apoptosis [328, 329]. Such a deep involvement in the mechanisms of extrinsic apoptosis makes VDAC2 a clear candidate for pharmacological intervention. Activity in this direction has however been limited so far. Besides WEHI9625, one compound binding VDAC2 (and VDAC1) is sulindac sulfone, a metabolite of the nonsteroidal anti-inflammatory drug sulindac [330]. VDAC2 is also involved in cell death induced by artesunate, a derivative of the antimalarian herbal drug artemisin [331]. A whole set of compounds, from resveratrol to paclitaxel to artesunate, act via Bak, and their action may therefore involve VDAC2. The possibility of an involvement of VDAC3 in cancer has received so far little attention. The protein has been proposed to function as a redox sensor, and may thus respond to the oxidizing conditions normally found in cancerous cells [332].

\section{CLIC}

Chloride intracellular channels (CLIC1-6) are one of the two classes of chloride channels identified in the IMM. They are still only partially understood [333]. CLICs exist in both soluble and membrane forms and are structurally similar to a family of glutathione 


\section{Cellular Physiology Cell Physiol Biochem 2019;53(S1):11-43 \\ \begin{tabular}{ll|l} 
and Biochemistry $10.33594 / 000000192$ & DOlished online: 14 December 2019 & $\begin{array}{l}\text { C } 2019 \text { The Author(s). Published by } \\
\text { Cell Physiol Biochem Press GmbH\&Co. KG }\end{array}$
\end{tabular} \\ Parrasia et al.: Drugs vs Mitochondrial Channels in Cancer}

S-transferases, but they can insert into membranes to form ion channels [334]. Membraneassociated CLICs are localized in the nuclear membrane, trans-Golgi network, endoplasmic reticulum and mitochondria, and their distribution is tissue specific. They participate in membrane trafficking, cytoskeletal function, apoptosis, cell cycle control, tubulogenesis and other cellular processes. It has been demonstrated that CLIC1, CLIC4 and CLIC5 are present in adult cardiac mitochondria [335]. Since a sub-fraction of CLIC4 has been identified in the IMM, it has been proposed to have a role in the regulation of membrane potential $[335,336]$. CLIC4 has also been observed in the mitochondria of keratinocytes [337].

CLICs definitely have a role in cancerogenesis, but our knowledge is still spotty [338]. Both up- and down-regulation have been reported in cancer cell lines, and the various members of the family clearly have different characteristics and functions. Thus, e.g., a correlation was found between tumor grade and percentage of CLIC1 positive cells in renal carcinoma [339]. CLIC1 expression was elevated in glioblastoma in comparison with lowgrade glioma [340] and its downregulation by shRNA or antibody treatment in neurospheres reduced the proliferation and tumorigenicity of cancer stem cells [341]. Biguanide drugs (including metformin) selectively inhibit CLIC1 in glioblastoma stem cells and oppose their proliferation and invasiveness, with little effect on normal stem cells [342, 343]. Overexpression of CLIC-4 was reported in malignant pleura mesothelioma patients [344]. CLIC4 was instead downregulated in several epithelial cancers and squamous cancer cell lines. The expression of the protein was inversely correlated with the malignancy of these tumors. CLIC4 expression is controlled by p53 and TNF $\alpha$ and the protein has been observed to translocate from the cytosol to the nucleus under conditions of oxidative stress. Auranofin, an inhibitor of thioredoxin reductase, induced this migration in $\mathrm{v}$-ras ${ }^{\mathrm{Ha}}$-transformed primary keratinocytes but not normal primary keratinocytes [345]. ROS trigger the upregulation of CLIC4 expression in ovarian cancers [346]. Other studies reported, upon an increase in oxidative stress, an increase of CLIC4 protein expression in the glioma C6 cell line. This behavior was paralleled by an increased Bax/Bcl-2 ratio, cytochrome $\mathrm{c}$ and cleaved caspase-3 protein expression upon $\mathrm{H}_{2} \mathrm{O}_{2}$-induced $\mathrm{C} 6$ cell apoptosis, indicating that CLIC4 could be involved in oxidative stress-triggered apoptosis [347]. CLIC4 is thus considered to be a tumor suppressor protein.

The pharmacology of these proteins is, unsurprisingly, still underdeveloped. In addition to the biguanide drugs mentioned above, Indanyloxyacetic acid (IAA)-94 (a chloride channel inhibitor) reduced colon cancer cell migration and invasion, and the effect was attributed to inhibition of CLIC1 [348].

Summarizing, the knowledge on CLICs implications in cancer is still insufficient, especially with regard to mitochondrial populations of the channels. Despite the lack of causal evidences, variations in the expression pattern of (some of) these proteins in cancer makes them interesting topics for further mechanistic and pharmacological investigation.

\section{Conclusion}

Collectively, mitochondrial channels have an outstanding potential as targets for innovative chemotherapeutic approaches. Their location allows them to influence aspects of cell biochemistry/physiology of peculiar relevance in cancer, so that drugs targeting them have a selective impact on cancerous cells. In most cases (exceptions: MCUC, $\mathrm{K}_{\mathrm{ATP}}$ ) the mitochondrial population is only a fraction of the total amount expressed by the cell. Focalized targeting thus requires fielding appropriately modified drugs, usually containing a lipophilic cation, and/or specially equipped nanovehicles. It should also be kept firmly in mind that each cancer has its own specific features, and this applies to mitochondrial channels as well as to many other aspects.

The progress made to date towards a possible clinical use varies greatly from case to case. For some mitochondrial channels the connection with cancer has hardly been made, and might not be significant (e.g. $\mathrm{K}_{\mathrm{ATP}}, \mathrm{BK}_{\mathrm{Ca}}$ ). In other cases it is known to exist, but it is 


\section{$\begin{array}{cll}\text { Cellular Physiology } & \text { Cell Physiol Biochem 2019;53(S1):11-43 } \\ \text { DOl: 10.33594/000000192 } & \text { O 2019 The Author(s). Published by } \\ \text { and Biochemistry } & \text { Published online: 14 December 2019 } & \text { Cell Physiol Biochem Press GmbH\&Co. KG }\end{array}$

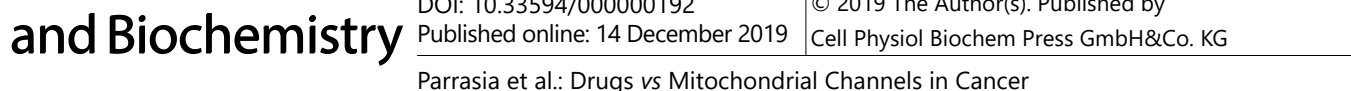

still insufficiently defined and/or there is essentially no pharmacology to build on (e.g., CLIC4). For a few channels definite steps forward have been made or are being taken. These are MCUC and VDAC, for which mitochondrial targeting is no - or a secondary - problem, and some of the IMM K $\mathrm{K}^{+}$channels. The latter have counterparts elsewhere in the cell, and thus a pharmacological approach directed specifically to mitochondria may be fruitful. A detailed investigation of the characteristics and functions of mitochondrial channels in cancer cell lines, including those that are known to exist but have been rather neglected thus far, is a prerequisite for the expansion and development of this emerging branch of oncopharmacology.

\section{Acknowledgements}

We thank I. Szabò, C. Paradisi, M.P. Rigobello, E. Gulbins and their groups for useful interactions and collaboration.

Statement of Ethics

The authors have no ethical conflicts to disclose.

Funding Sources

University of Padua (STARS Grants programme "CHEMPROCALIM" to A.M.) and Department of Pharmaceutical and Pharmacological Sciences (UniPD) MAT_SID17_01 to A.M.

Author Contributions

All the authors wrote and critically revised the manuscript.

\section{Disclosure Statement}

The authors have no conflicts of interest to declare.

\section{References}

1 Nguyen C, Pandey S: Exploiting Mitochondrial Vulnerabilities to Trigger Apoptosis Selectively in Cancer Cells. Cancers (Basel) 2019;11:pii:E916.

2 Porporato PE, Filigheddu N, Pedro JMB, Kroemer G, Galluzzi L: Mitochondrial metabolism and cancer. Cell Res 2018;28:265-280.

3 Leanza L, Manago A, Zoratti M, Gulbins E, Szabo I: Pharmacological targeting of ion channels for cancer therapy: In vivo evidences. Biochim Biophys Acta 2016;1863:1385-1397.

4 Ryan DG, Murphy MP, Frezza C, Prag HA, Chouchani ET, O’Neill LA, Mills EL: Coupling Krebs cycle metabolites to signalling in immunity and cancer. Nat Metab 2019;1:16-33.

5 Idelchik M, Begley U, Begley TJ, Melendez JA: Mitochondrial ROS control of cancer. Semin Cancer Biol 2017;47:57-66.

6 Ralph SJ, Nozuhur S, ALHulais RA, Rodriguez-Enriquez S, Moreno-Sanchez R: Repurposing drugs as prooxidant redox modifiers to eliminate cancer stem cells and improve the treatment of advanced stage cancers. Med Res Rev 2019;39:2397-2426.

7 Chen H, Chan DC: Mitochondrial Dynamics in Regulating the Unique Phenotypes of Cancer and Stem Cells. Cell Metab 2017;26:39-48.

8 Fiorillo M, Sotgia F, Lisanti MP: “Energetic” Cancer Stem Cells (e-CSCs): A New Hyper-Metabolic and Proliferative Tumor Cell Phenotype, Driven by Mitochondrial Energy. Front Oncol 2018;8:677.

9 Shin MK, Cheong JH: Mitochondria-centric bioenergetic characteristics in cancer stem-like cells. Arch Pharm Res 2019;42:113-127. 


\section{Cellular Physiology Cell Physiol Biochem 2019;53(S1):11-43 \begin{tabular}{l|l|l} 
and Biol: 10.33594/000000192 & (c)19 The Author(s). Published by
\end{tabular} and BiOChemistry Published online: 14 December 2019 Cell Physiol Biochem Press GmbH\&Co. KG \\ Parrasia et al.: Drugs vs Mitochondrial Channels in Cancer}

10 Deshmukh A, Deshpande K, Arfuso F, Newsholme P, Dharmarajan A: Cancer stem cell metabolism: a potential target for cancer therapy. Mol Cancer 2016;15:69.

11 Leanza L, Checchetto V, Biasutto L, Rossa A, Costa R, Bachmann M, Zoratti M, Szabo I: Pharmacological modulation of mitochondrial ion channels. Br J Pharmacol 2018; DOI:10.1111/bph.14544.

12 Peruzzo R, Biasutto L, Szabo I, Leanza L: Impact of intracellular ion channels on cancer development and progression. Eur Biophys J 2016;45:685-707.

13 Bachmann M, Costa R, Peruzzo R, Prosdocimi E, Checchetto V, Leanza L: Targeting Mitochondrial Ion Channels to Fight Cancer. Int J Mol Sci 2018;19:pii:E2060.

14 Leanza L, O’Reilly P, Doyle A, Venturini E, Zoratti M, Szegezdi E, Szabo I: Correlation between potassium channel expression and sensitivity to drug-induced cell death in tumor cell lines. Curr Pharm Des 2014;20:189-200.

15 Peruzzo R, Szabo I: Contribution of Mitochondrial Ion Channels to Chemo-Resistance in Cancer Cells. Cancers (Basel) 2019;11:pii:E761.

16 Loureiro R, Mesquita KA, Magalhaes-Novais S, Oliveira PJ, Vega-Naredo I: Mitochondrial biology in cancer stem cells. Semin Cancer Biol 2017;47:18-28.

17 Sica V, Bravo-San Pedro JM, Stoll G, Kroemer G: Oxidative phosphorylation as a potential therapeutic target for cancer therapy. Int J Cancer 2019; DOI:10.1002/ijc.32616.

18 Chau CH, Steeg PS, Figg WD: Antibody-drug conjugates for cancer. Lancet 2019;394:793-804.

19 Dewhirst MW, Secomb TW: Transport of drugs from blood vessels to tumour tissue. Nat Rev Cancer 2017;17:738-750.

20 Ahmad A, Khan F, Mishra RK, Khan R: Precision Cancer Nanotherapy: Evolving Role of Multifunctional Nanoparticles for Cancer Active Targeting. J Med Chem 2019; DOI:10.1021/acs.jmedchem.9b00511.

21 Delahousse J, Skarbek C, Paci A: Prodrugs as drug delivery system in oncology. Cancer Chemother Pharmacol 2019;84:937-958.

22 Zheng N, Tsai HN, Zhang X, Shedden K, Rosania GR: The subcellular distribution of small molecules: a metaanalysis. Mol Pharm 2011;8:1611-1618.

23 Liberman EA, Topaly VP, Tsofina LM, Jasaitis AA, Skulachev VP: Mechanism of coupling of oxidative phosphorylation and the membrane potential of mitochondria. Nature 1969;222:1076-1078.

24 Biasutto L, Mattarei A, La Spina M, Azzolini M, Parrasia S, Szabo I, Zoratti M: Strategies to target bioactive molecules to subcellular compartments. Focus on natural compounds. Eur J Med Chem 2019;181:111557.

25 Zielonka J, Joseph J, Sikora A, Hardy M, Ouari O, Vasquez-Vivar J, Cheng G, Lopez M, Kalyanaraman B: Mitochondria-Targeted Triphenylphosphonium-Based Compounds: Syntheses, Mechanisms of Action, and Therapeutic and Diagnostic Applications. Chem Rev 2017;117:10043-10120.

26 James AM, Sharpley MS, Manas AR, Frerman FE, Hirst J, Smith RA, Murphy MP: Interaction of the mitochondria-targeted antioxidant MitoQ with phospholipid bilayers and ubiquinone oxidoreductases. J Biol Chem 2007;282:14708-14718.

27 Zakharova LY, Kaupova GI, Gabdrakhmanov DR, Gaynanova GA, Ermakova EA, Mukhitov AR, Galkina IV, Cheresiz SV, Pokrovsky AG, Skvortsova PV, Gogolev YV, Zuev YF: Alkyl triphenylphosphonium surfactants as nucleic acid carriers: complexation efficacy toward DNA decamers, interaction with lipid bilayers and cytotoxicity studies. Phys Chem Chem Phys 2019;21:16706-16717.

28 Gazzano E, Lazzarato L, Rolando B, Kopecka J, Guglielmo S, Costamagna C, Chegaev K, Riganti C: Mitochondrial Delivery of Phenol Substructure Triggers Mitochondrial Depolarization and Apoptosis of Cancer Cells. Front Pharmacol 2018;9:580.

29 Ozsvari B, Sotgia F, Lisanti MP: Exploiting mitochondrial targeting signal(s), TPP and bis-TPP, for eradicating cancer stem cells (CSCs). Aging (Albany NY) 2018;10:229-240.

30 Reily C, Mitchell T, Chacko BK, Benavides G, Murphy MP, Darley-Usmar V: Mitochondrially targeted compounds and their impact on cellular bioenergetics. Redox Biol 2013;1:86-93.

31 Trnka J, Elkalaf M, Andel M: Lipophilic triphenylphosphonium cations inhibit mitochondrial electron transport chain and induce mitochondrial proton leak. PLoS One 2015;10:e0121837.

32 Sassi N, Mattarei A, Azzolini M, Szabo I, Paradisi C, Zoratti M, Biasutto L: Cytotoxicity of mitochondriatargeted resveratrol derivatives: interactions with respiratory chain complexes and ATP synthase. Biochim Biophys Acta 2014;1837:1781-1789. 


\section{Cellular Physiology Cell Physiol Biochem 2019;53(S1):11-43 \begin{tabular}{ll|l} 
and Biol: 10.33594/000000192 & (c)19 The Author(s). Published by
\end{tabular} and Biochemistry Published online: 14 December 2019 Cell Physiol Biochem Press GmbH\&Co. KG \\ Parrasia et al.: Drugs vs Mitochondrial Channels in Cancer}

33 Kalyanaraman B, Cheng G, Hardy M, Ouari O, Lopez M, Joseph J, Zielonka J, Dwinell MB: A review of the basics of mitochondrial bioenergetics, metabolism, and related signaling pathways in cancer cells: Therapeutic targeting of tumor mitochondria with lipophilic cationic compounds. Redox Biol 2018;14:316327.

34 Kiselyov K, Muallem S: ROS and intracellular ion channels. Cell Calcium 2016;60:108-114.

35 Wang F, Ogasawara MA, Huang P: Small mitochondria-targeting molecules as anti-cancer agents. Mol Aspects Med 2010;31:75-92.

36 Weissig V, Lasch J, Erdos G, Meyer HW, Rowe TC, Hughes J: DQAsomes: a novel potential drug and gene delivery system made from Dequalinium. Pharm Res 1998;15:334-337.

37 Weissig V, Boddapati SV, Cheng SM, D’Souza GG: Liposomes and liposome-like vesicles for drug and DNA delivery to mitochondria. J Liposome Res 2006;16:249-264.

38 Grzybowski M, Glodkowska-Mrowka E, Hugues V, Brutkowski W, Blanchard-Desce M, Gryko DT: Polar diketopyrrolopyrrole-imidazolium salts as selective probes for staining mitochondria in two-photon fluorescence microscopy. Chemistry 2015;21:9101-9110.

39 Sibrian-Vazquez M, Nesterova IV, Jensen TJ, Vicente MG: Mitochondria targeting by guanidine- and biguanidine-porphyrin photosensitizers. Bioconjug Chem 2008;19:705-713.

40 Antonenko YN, Avetisyan AV, Bakeeva LE, Chernyak BV, Chertkov VA, Domnina LV, Ivanova OY, Izyumov DS, Khailova LS, Klishin SS, Korshunova GA, Lyamzaev KG, Muntyan MS, Nepryakhina OK, Pashkovskaya AA, Pletjushkina OY, Pustovidko AV, Roginsky VA, Rokitskaya TI, Ruuge EK, et al.: Mitochondria-targeted plastoquinone derivatives as tools to interrupt execution of the aging program. 1. Cationic plastoquinone derivatives: synthesis and in vitro studies. Biochemistry (Mosc) 2008;73:1273-1287.

41 Chen H, Wang J, Feng X, Zhu M, Hoffmann S, Hsu A, Qian K, Huang D, Zhao F, Liu W, Zhang H, Cheng Z: Mitochondria-targeting fluorescent molecules for high efficiency cancer growth inhibition and imaging. Chemical Science 2019;10:7946-7951.

42 Koya K, Li Y, Wang H, Ukai T, Tatsuta N, Kawakami M, Shishido, Chen LB: MKT-077, a novel rhodacyanine dye in clinical trials, exhibits anticarcinoma activity in preclinical studies based on selective mitochondrial accumulation. Cancer Res 1996;56:538-543.

43 Britten CD, Rowinsky EK, Baker SD, Weiss GR, Smith L, Stephenson J, Rothenberg M, Smetzer L, Cramer J, Collins W, Von Hoff DD, Eckhardt SG: A phase I and pharmacokinetic study of the mitochondrial-specific rhodacyanine dye analog MKT 077. Clin Cancer Res 2000;6:42-49.

44 Jean SR, Ahmed M, Lei EK, Wisnovsky SP, Kelley SO: Peptide-Mediated Delivery of Chemical Probes and Therapeutics to Mitochondria. Acc Chem Res 2016;49:1893-1902.

45 Chen ZP, Li M, Zhang LJ, He JY, Wu L, Xiao YY, Duan JA, Cai T, Li WD: Mitochondria-targeted drug delivery system for cancer treatment. J Drug Target 2016;24:492-502.

46 Czupiel PP, Delplace V, Shoichet MS: Cationic block amphiphiles show anti-mitochondrial activity in multidrug resistant breast cancer cells. J Control Release 2019;305:210-219.

47 Buondonno I, Gazzano E, Jean SR, Audrito V, Kopecka J, Fanelli M, Salaroglio IC, Costamagna C, Roato I, Mungo E, Hattinger CM, Deaglio S, Kelley SO, Serra M, Riganti C: Mitochondria-Targeted Doxorubicin: A New Therapeutic Strategy against Doxorubicin-Resistant Osteosarcoma. Mol Cancer Ther 2016;15:26402652.

48 Fonseca SB, Pereira MP, Mourtada R, Gronda M, Horton KL, Hurren R, Minden MD, Schimmer AD, Kelley SO: Rerouting chlorambucil to mitochondria combats drug deactivation and resistance in cancer cells. Chem Biol 2011;18:445-453.

49 Vestweber D, Schatz G: DNA-protein conjugates can enter mitochondria via the protein import pathway. Nature 1989;338:170-172.

50 Flierl A, Jackson C, Cottrell B, Murdock D, Seibel P, Wallace DC: Targeted delivery of DNA to the mitochondrial compartment via import sequence-conjugated peptide nucleic acid. Mol Ther 2003;7:550557.

51 Kawamura E, Yamada Y, Harashima H: Mitochondrial targeting functional peptides as potential devices for the mitochondrial delivery of a DF-MITO-Porter. Mitochondrion 2013;13:610-614.

52 Battigelli A, Russier J, Venturelli E, Fabbro C, Petronilli V, Bernardi P, Da Ros T, Prato M, Bianco A: Peptidebased carbon nanotubes for mitochondrial targeting. Nanoscale 2013;5:9110-9117.

53 Battogtokh G, Cho YY, Lee JY, Lee HS, Kang HC: Mitochondrial-Targeting Anticancer Agent Conjugates and Nanocarrier Systems for Cancer Treatment. Front Pharmacol 2018;9:922. 


\section{Cellular Physiology Cell Physiol Biochem 2019;53(S1):11-43 \begin{tabular}{l|l|l}
\cline { 3 - 3 } DOI: 10.33594/000000192 & ( 2019 The Author(s). Published by
\end{tabular} and Biochemistry Published online: 14 December 2019 Cell Physiol Biochem Press GmbH\&Co. KG \\ Parrasia et al.: Drugs vs Mitochondrial Channels in Cancer}

54 Maity AR, Stepensky D: Limited Efficiency of Drug Delivery to Specific Intracellular Organelles Using Subcellularly “Targeted” Drug Delivery Systems. Mol Pharm 2016;13:1-7.

55 Marrache S, Dhar S: Engineering of blended nanoparticle platform for delivery of mitochondria-acting therapeutics. Proc Natl Acad Sci U S A 2012;109:16288-16293.

56 Naz S, Wang M, Han Y, Hu B, Teng L, Zhou J, Zhang H, Chen J: Enzyme-responsive mesoporous silica nanoparticles for tumor cells and mitochondria multistage-targeted drug delivery. Int J Nanomedicine 2019;14:2533-2542.

57 Singh Y, Viswanadham K, Pawar VK, Meher J, Jajoriya AK, Omer A, Jaiswal S, Dewangan J, Bora HK, Singh P, Rath SK, Lal J, Mishra DP, Chourasia MK: Induction of Mitochondrial Cell Death and Reversal of Anticancer Drug Resistance via Nanocarriers Composed of a Triphenylphosphonium Derivative of Tocopheryl Polyethylene Glycol Succinate. Mol Pharm 2019;16:3744-3759.

58 Benien P, Almuteri MA, Mehanna AS, D’Souza GG: Synthesis of triphenylphosphonium phospholipid conjugates for the preparation of mitochondriotropic liposomes. Methods Mol Biol 2015;1265:51-57.

59 Deshpande P, Jhaveri A, Pattni B, Biswas S, Torchilin V: Transferrin and octaarginine modified dualfunctional liposomes with improved cancer cell targeting and enhanced intracellular delivery for the treatment of ovarian cancer. Drug Deliv 2018;25:517-532.

60 Katayama T, Kinugawa S, Takada S, Furihata T, Fukushima A, Yokota T, Anzai T, Hibino M, Harashima H, Yamada Y: A mitochondrial delivery system using liposome-based nanocarriers that target myoblast cells. Mitochondrion 2019;49:66-72.

61 Nakamura T, Yamada Y, Sato Y, Khalil IA, Harashima H: Innovative nanotechnologies for enhancing nucleic acids/gene therapy: Controlling intracellular trafficking to targeted biodistribution. Biomaterials 2019;218:119329.

62 Abe J, Yamada Y, Takeda A, Harashima H: Cardiac progenitor cells activated by mitochondrial delivery of resveratrol enhance the survival of a doxorubicin-induced cardiomyopathy mouse model via the mitochondrial activation of a damaged myocardium. J Control Release 2018;269:177-188.

63 Sileikyte J, Forte M: The Mitochondrial Permeability Transition in Mitochondrial Disorders. Oxid Med Cell Longev 2019;2019:3403075.

64 Biasutto L, Azzolini M, Szabo I, Zoratti M: The mitochondrial permeability transition pore in AD 2016: An update. Biochim Biophys Acta 2016;1863:2515-2530.

65 Bernardi P, Rasola A, Forte M, Lippe G: The Mitochondrial Permeability Transition Pore: Channel Formation by F-ATP Synthase, Integration in Signal Transduction, and Role in Pathophysiology. Physiol Rev 2015;95:1111-1155.

66 Urbani A, Giorgio V, Carrer A, Franchin C, Arrigoni G, Jiko C, Abe K, Maeda S, Shinzawa-Itoh K, Bogers JFM, McMillan DGG, Gerle C, Szabo I, Bernardi P: Purified F-ATP synthase forms a Ca(2+)-dependent high-conductance channel matching the mitochondrial permeability transition pore. Nat Commun 2019;10:4341.

67 Carraro M, Checchetto V, Szabo I, Bernardi P: F-ATP synthase and the permeability transition pore: fewer doubts, more certainties. FEBS Lett 2019;593:1542-1553.

68 Giorgio V, Burchell V, Schiavone M, Bassot C, Minervini G, Petronilli V, Argenton F, Forte M, Tosatto S, Lippe G, Bernardi P: $\mathrm{Ca}(2+)$ binding to F-ATP synthase beta subunit triggers the mitochondrial permeability transition. EMBO Rep 2017;18:1065-1076.

69 Rottenberg H, Hoek JB: The path from mitochondrial ROS to aging runs through the mitochondrial permeability transition pore. Aging Cell 2017;16:943-955.

70 Sileikyte J, Devereaux J, de Jong J, Schiavone M, Jones K, Nilsen A, Bernardi P, Forte M, Cohen MS: SecondGeneration Inhibitors of the Mitochondrial Permeability Transition Pore with Improved Plasma Stability. ChemMedChem 2019;14:1771-1782.

71 Rimessi A, Pedriali G, Vezzani B, Tarocco A, Marchi S, Wieckowski MR, Giorgi C, Pinton P: Interorganellar calcium signaling in the regulation of cell metabolism: A cancer perspective. Semin Cell Dev Biol 2019; DOI:10.1016/j.semcdb.2019.05.015.

72 Moloney JN, Cotter TG: ROS signalling in the biology of cancer. Semin Cell Dev Biol 2018;80:50-64.

73 Rasola A, Bernardi P: The mitochondrial permeability transition pore and its adaptive responses in tumor cells. Cell Calcium 2014;56:437-445. 


\section{Cellular Physiology Cell Physiol Biochem 2019;53(S1):11-43 \begin{tabular}{ll|l} 
and Biochemistry $10.33594 / 000000192$ & C 2019 The Author(s). Published by \\
Published online: 14 December 2019 & Cell Physiol Biochem Press GmbH\&Co. KG
\end{tabular} \\ Parrasia et al.: Drugs vs Mitochondrial Channels in Cancer}

74 Qian Q, Chen W, Cao Y, Cao Q, Cui Y, Li Y, Wu J: Targeting Reactive Oxygen Species in Cancer via Chinese Herbal Medicine. Oxid Med Cell Longev 2019;2019:9240426.

75 Chiara F, Gambalunga A, Sciacovelli M, Nicolli A, Ronconi L, Fregona D, Bernardi P, Rasola A, Trevisan A: Chemotherapeutic induction of mitochondrial oxidative stress activates GSK-3alpha/beta and Bax, leading to permeability transition pore opening and tumor cell death. Cell Death Dis 2012;3:e444.

76 Scalcon V, Bindoli A, Rigobello MP: Significance of the mitochondrial thioredoxin reductase in cancer cells: An update on role, targets and inhibitors. Free Radic Biol Med 2018;127:62-79.

77 Hempel N, Trebak M: Crosstalk between calcium and reactive oxygen species signaling in cancer. Cell Calcium 2017;63:70-96.

78 Gorrini C, Harris IS, Mak TW: Modulation of oxidative stress as an anticancer strategy. Nat Rev Drug Discov 2013;12:931-947.

79 Ekinci E, Rohondia S, Khan R, Dou QP: Repurposing Disulfiram as An Anti-Cancer Agent: Updated Review on Literature and Patents. Recent Pat Anticancer Drug Discov 2019;14:113-132.

80 Han Y, Chen P, Zhang Y, Lu W, Ding W, Luo Y, Wen S, Xu R, Liu P, Huang P: Synergy between Auranofin and Celecoxib against Colon Cancer In vitro and In vivo through a Novel Redox-Mediated Mechanism. Cancers (Basel) 2019;11:pii:E931.

81 Zhang X, Zhu Y, Dong S, Zhang A, Lu Y, Li Y, Lv S, Zhang J: Role of oxidative stress in cardiotoxicity of antineoplastic drugs. Life Sci 2019;232:116526.

82 Cheng Y, Qi Y: Current Progresses in Metal-based Anticancer Complexes as Mammalian TrxR Inhibitors. Anticancer Agents Med Chem 2017;17:1046-1069.

83 Gandin V, Fernandes AP: Metal- and Semimetal-Containing Inhibitors of Thioredoxin Reductase as Anticancer Agents. Molecules 2015;20:12732-12756.

84 Fernandes AP, Gandin V: Selenium compounds as therapeutic agents in cancer. Biochim Biophys Acta 2015;1850:1642-1660.

85 Babak MV, Zhi Y, Czarny B, Toh TB, Hooi L, Chow EK, Ang WH, Gibson D, Pastorin G: Dual-Targeting DualAction Platinum(IV) Platform for Enhanced Anticancer Activity and Reduced Nephrotoxicity. Angew Chem Int Ed Engl 2019;58:8109-8114.

86 Stevens JF, Revel JS, Maier CS: Mitochondria-Centric Review of Polyphenol Bioactivity in Cancer Models. Antioxid Redox Signal 2018;29:1589-1611.

87 NavaneethaKrishnan S, Rosales JL, Lee KY: ROS-Mediated Cancer Cell Killing through Dietary Phytochemicals. Oxid Med Cell Longev 2019;2019:9051542.

88 Zhang J, Li X, Han X, Liu R, Fang J: Targeting the Thioredoxin System for Cancer Therapy. Trends Pharmacol Sci 2017;38:794-808.

89 Zhang J, Zhang B, Li X, Han X, Liu R, Fang J: Small molecule inhibitors of mammalian thioredoxin reductase as potential anticancer agents: An update. Med Res Rev 2019;39:5-39.

90 Flescher E: Jasmonates--a new family of anti-cancer agents. Anticancer Drugs 2005;16:911-916.

91 Zoratti M, Szabo I: The mitochondrial permeability transition. Biochim Biophys Acta 1995;1241:139-176.

92 Elustondo PA, Nichols M, Negoda A, Thirumaran A, Zakharian E, Robertson GS, Pavlov EV: Mitochondrial permeability transition pore induction is linked to formation of the complex of ATPase C-subunit, polyhydroxybutyrate and inorganic polyphosphate. Cell Death Discov 2016;2:16070.

93 Le Quoc K, Le Quoc D: Involvement of the ADP/ATP carrier in calcium-induced perturbations of the mitochondrial inner membrane permeability: importance of the orientation of the nucleotide binding site. Arch Biochem Biophys 1988;265:249-257.

94 Morin D, Zini R, Ligeret H, Neckameyer W, Labidalle S, Tillement JP: Dual effect of ebselen on mitochondrial permeability transition. Biochem Pharmacol 2003;65:1643-1651.

95 Zoratti M, Szabo I, De Marchi U: Mitochondrial permeability transitions: how many doors to the house? Biochim Biophys Acta 2005;1706:40-52.

96 Fu M, Shi W, Li Z, Liu H: Activation of mPTP-dependent mitochondrial apoptosis pathway by a novel pan HDAC inhibitor resminostat in hepatocellular carcinoma cells. Biochem Biophys Res Commun 2016;477:527-533.

97 Giorgio V, von Stockum S, Antoniel M, Fabbro A, Fogolari F, Forte M, Glick GD, Petronilli V, Zoratti M, Szabo I, Lippe G, Bernardi P: Dimers of mitochondrial ATP synthase form the permeability transition pore. Proc Natl Acad Sci U S A 2013;110:5887-5892. 


\section{Cellular Physiology Cell Physiol Biochem 2019;53(S1):11-43 \begin{tabular}{l|l|l} 
and Binch 2019 The Author(s). Published by \\
\hline
\end{tabular} and BiOChemistry Published online: 14 December 2019 Cell Physiol Biochem Press GmbH\&Co. KG \\ Parrasia et al.: Drugs vs Mitochondrial Channels in Cancer}

98 Montagner D, Fresch B, Browne K, Gandin V, Erxleben A: A Cu(ii) complex targeting the translocator protein: in vitro and in vivo antitumor potential and mechanistic insights. Chem Commun (Camb) 2016;53:134-137.

99 Mammucari C, Raffaello A, Vecellio Reane D, Gherardi G, De Mario A, Rizzuto R: Mitochondrial calcium uptake in organ physiology: from molecular mechanism to animal models. Pflugers Arch 2018;470:11651179.

100 Feno S, Butera G, Vecellio Reane D, Rizzuto R, Raffaello A: Crosstalk between Calcium and ROS in Pathophysiological Conditions. Oxid Med Cell Longev 2019;2019:9324018.

101 Snezhkina AV, Kudryavtseva AV, Kardymon OL, Savvateeva MV, Melnikova NV, Krasnov GS, Dmitriev AA: ROS Generation and Antioxidant Defense Systems in Normal and Malignant Cells. Oxid Med Cell Longev 2019;2019:6175804.

102 Liao Z, Chua D, Tan NS: Reactive oxygen species: a volatile driver of field cancerization and metastasis. Mol Cancer 2019;18:65.

103 De Stefani D, Rizzuto R, Pozzan T: Enjoy the Trip: Calcium in Mitochondria Back and Forth. Annu Rev Biochem 2016;85:161-192.

104 Wacquier B, Combettes L, Dupont G: Cytoplasmic and Mitochondrial Calcium Signaling: A Two-Way Relationship. Cold Spring Harb Perspect Biol 2019;11:

105 Terrie E, Coronas V, Constantin B: Role of the calcium toolkit in cancer stem cells. Cell Calcium 2019;80:141-151.

106 Zhong T, Pan X, Wang J, Yang B, Ding L: The regulatory roles of calcium channels in tumors. Biochem Pharmacol 2019;169:113603.

107 Cui C, Yang J, Fu L, Wang M, Wang X: Progress in understanding mitochondrial calcium uniporter complexmediated calcium signalling: A potential target for cancer treatment. Br J Pharmacol 2019;176:1190-1205.

108 Marchi S, Vitto VAM, Danese A, Wieckowski MR, Giorgi C, Pinton P: Mitochondrial calcium uniporter complex modulation in cancerogenesis. Cell Cycle 2019;18:1068-1083.

109 Vultur A, Gibhardt CS, Stanisz H, Bogeski I: The role of the mitochondrial calcium uniporter (MCU) complex in cancer. Pflugers Arch 2018;470:1149-1163.

110 Pallafacchina G, Zanin S, Rizzuto R: Recent advances in the molecular mechanism of mitochondrial calcium uptake. F1000Res 2018; DOI:10.12688/f1000research.15723.

111 Paillard M, Csordas G, Szanda G, Golenar T, Debattisti V, Bartok A, Wang N, Moffat C, Seifert EL, Spat A, Hajnoczky G: Tissue-Specific Mitochondrial Decoding of Cytoplasmic $\mathrm{Ca}(2+)$ Signals Is Controlled by the Stoichiometry of MICU1/2 and MCU. Cell Rep 2017;18:2291-2300.

112 Garcia-Rivas Gde J, Carvajal K, Correa F, Zazueta C: Ru360, a specific mitochondrial calcium uptake inhibitor, improves cardiac post-ischaemic functional recovery in rats in vivo. Br J Pharmacol 2006;149:829-837.

113 Anghileri LJ: The in vivo inhibition of tumor growth by ruthenium red: its relationship with the metabolism of calcium in the tumor. Z Krebsforsch Klin Onkol Cancer Res Clin Oncol 1975;83:213-217.

114 Woods JJ, Nemani N, Shanmughapriya S, Kumar A, Zhang M, Nathan SR, Thomas M, Carvalho E, Ramachandran K, Srikantan S, Stathopulos PB, Wilson JJ, Madesh M: A Selective and Cell-Permeable Mitochondrial Calcium Uniporter (MCU) Inhibitor Preserves Mitochondrial Bioenergetics after Hypoxia/ Reoxygenation Injury. ACS Cent Sci 2019;5:153-166.

115 Phillips AMF, Pombeiro AJL: Tansition Metal-Based Prodrugs for Anticancer Drug Delivery. Curr Med Chem 2018; DOI:10.2174/0929867326666181203141122.

116 Crompton M, Heid I, Baschera C, Carafoli E: The resolution of calcium fluxes in heart and liver mitochondria using the lanthanide series. FEBS Lett 1979;104:352-354.

117 Schwartz J, Holmuhamedov E, Zhang X, Lovelace GL, Smith CD, Lemasters JJ: Minocycline and doxycycline, but not other tetracycline-derived compounds, protect liver cells from chemical hypoxia and ischemia/ reperfusion injury by inhibition of the mitochondrial calcium uniporter. Toxicol Appl Pharmacol 2013;273:172-179.

118 Markowska A, Kaysiewicz J, Markowska J, Huczynski A: Doxycycline, salinomycin, monensin and ivermectin repositioned as cancer drugs. Bioorg Med Chem Lett 2019;29:1549-1554.

119 Kon N, Murakoshi M, Isobe A, Kagechika K, Miyoshi N, Nagayama T: DS16570511 is a small-molecule inhibitor of the mitochondrial calcium uniporter. Cell Death Discov 2017;3:17045. 


\section{Cellular Physiology Cell Physiol Biochem 2019;53(S1):11-43 \begin{tabular}{l|l|l} 
and Biol: 10.33594/000000192 & (c)19 The Author(s). Published by
\end{tabular} and BiOChemistry Published online: 14 December 2019 Cell Physiol Biochem Press GmbH\&Co. KG \\ Parrasia et al.: Drugs vs Mitochondrial Channels in Cancer}

120 Payne R, Li C, Fernandez-Garcia E, Vais H, Foskett K: The MCU Inhibitor Ds16570511 has Off-Target Effects on Mitochondrial Membrane Potential. Biophysical Journal 2019;116:270a.

121 Santo-Domingo J, Vay L, Hernandez-Sanmiguel E, Lobaton CD, Moreno A, Montero M, Alvarez J: The plasma membrane $\mathrm{Na}+\mathrm{Ca} 2+$ exchange inhibitor KB-R7943 is also a potent inhibitor of the mitochondrial Ca2+ uniporter. Br J Pharmacol 2007;151:647-654.

122 Brustovetsky T, Brittain MK, Sheets PL, Cummins TR, Pinelis V, Brustovetsky N: KB-R7943, an inhibitor of the reverse $\mathrm{Na}+\mathrm{Ca} 2+$ exchanger, blocks $\mathrm{N}$-methyl-D-aspartate receptor and inhibits mitochondrial complex I. Br J Pharmacol 2011;162:255-270.

123 Arduino DM, Wettmarshausen J, Vais H, Navas-Navarro P, Cheng Y, Leimpek A, Ma Z, Delrio-Lorenzo A, Giordano A, Garcia-Perez C, Medard G, Kuster B, Garcia-Sancho J, Mokranjac D, Foskett JK, Alonso MT, Perocchi F: Systematic Identification of MCU Modulators by Orthogonal Interspecies Chemical Screening. Mol Cell 2017;67:711-723.e717.

124 Landowski TH, Megli CJ, Nullmeyer KD, Lynch RM, Dorr RT: Mitochondrial-mediated disregulation of Ca2+ is a critical determinant of Velcade (PS-341/bortezomib) cytotoxicity in myeloma cell lines. Cancer Res 2005;65:3828-3836.

125 Rustenbeck I, Eggers G, Reiter H, Munster W, Lenzen S: Polyamine modulation of mitochondrial calcium transport. I. Stimulatory and inhibitory effects of aliphatic polyamines, aminoglucosides and other polyamine analogues on mitochondrial calcium uptake. Biochem Pharmacol 1998;56:977-985.

126 Bastian A, Thorpe JE, Disch BC, Bailey-Downs LC, Gangjee A, Devambatla RK, Henthorn J, Humphries KM, Vadvalkar SS, Ihnat MA: A small molecule with anticancer and antimetastatic activities induces rapid mitochondrial-associated necrosis in breast cancer. J Pharmacol Exp Ther 2015;353:392-404.

127 Bastian A, Matsuzaki S, Humphries KM, Pharaoh GA, Doshi A, Zaware N, Gangjee A, Ihnat MA: AG311, a small molecule inhibitor of complex I and hypoxia-induced HIF-1alpha stabilization. Cancer Lett 2017;388:149-157.

128 Thu VT, Kim HK, Long le T, Lee SR, Hanh TM, Ko TH, Heo HJ, Kim N, Kim SH, Ko KS, Rhee BD, Han J: NecroX-5 prevents hypoxia/reoxygenation injury by inhibiting the mitochondrial calcium uniporter. Cardiovasc Res 2012;94:342-350.

129 Thu VT, Kim HK, Long le T, Nyamaa B, Song IS, Thuy TT, Huy NQ Marquez J, Kim SH, Kim N, Ko KS, Rhee BD, Han J: NecroX-5 protects mitochondrial oxidative phosphorylation capacity and preserves PGC1alpha expression levels during hypoxia/reoxygenation injury. Korean J Physiol Pharmacol 2016;20:201-211.

130 Park JH, Kim HK, Jung H, Kim KH, Kang MS, Hong JH, Yu BC, Park S, Seo SK, Choi IW, Kim SH, Kim N, Han J, Park SG: NecroX-5 prevents breast cancer metastasis by AKT inhibition via reducing intracellular calcium levels. Int J Oncol 2017;50:185-192.

131 Montero M, Lobaton CD, Hernandez-Sanmiguel E, Santodomingo J, Vay L, Moreno A, Alvarez J: Direct activation of the mitochondrial calcium uniporter by natural plant flavonoids. Biochem J 2004;384:19-24.

132 Cao C, Wang S, Cui T, Su XC, Chou JJ: Ion and inhibitor binding of the double-ring ion selectivity filter of the mitochondrial calcium uniporter. Proc Natl Acad Sci U S A 2017;114:E2846-e2851.

133 Nemani N, Shanmughapriya S, Madesh M: Molecular regulation of MCU: Implications in physiology and disease. Cell Calcium 2018;74:86-93.

134 Joiner ML, Koval OM, Li J, He BJ, Allamargot C, Gao Z, Luczak ED, Hall DD, Fink BD, Chen B, Yang J, Moore SA, Scholz TD, Strack S, Mohler PJ, Sivitz WI, Song LS, Anderson ME: CaMKII determines mitochondrial stress responses in heart. Nature 2012;491:269-273.

135 Koncz P, Szanda G, Fulop L, Rajki A, Spat A: Mitochondrial Ca2+ uptake is inhibited by a concerted action of p38 MAPK and protein kinase D. Cell Calcium 2009;46:122-129.

136 Szanda G, Halasz E, Spat A: Protein kinases reduce mitochondrial Ca2+ uptake through an action on the outer mitochondrial membrane. Cell Calcium 2010;48:168-175.

137 De Stefani D, Raffaello A, Teardo E, Szabo I, Rizzuto R: A forty-kilodalton protein of the inner membrane is the mitochondrial calcium uniporter. Nature 2011;476:336-340.

138 Baughman JM, Perocchi F, Girgis HS, Plovanich M, Belcher-Timme CA, Sancak Y, Bao XR, Strittmatter L, Goldberger O, Bogorad RL, Koteliansky V, Mootha VK: Integrative genomics identifies MCU as an essential component of the mitochondrial calcium uniporter. Nature 2011;476:341-345.

139 Garlid KD, Paucek P: Mitochondrial potassium transport: the K(+) cycle. Biochim Biophys Acta 2003;1606:23-41. 


\section{Cellular Physiology Cell Physiol Biochem 2019;53(S1):11-43 \begin{tabular}{ll|l|l|l}
\hline DOI: 10.33594/000000192 & (O) 2019 The Author(s). Published by
\end{tabular} and Biochemistry Published online: 14 December 2019 Cell Physiol Biochem Press GmbH\&Co. KG \\ Parrasia et al.: Drugs vs Mitochondrial Channels in Cancer}

140 Tian C, Zhu R, Zhu L, Qiu T, Cao Z, Kang T: Potassium channels: structures, diseases, and modulators. Chem Biol Drug Des 2014;83:1-26.

141 Szabo I, Zoratti M: Mitochondrial channels: ion fluxes and more. Physiol Rev 2014;94:519-608.

142 Capera J, Serrano-Novillo C, Navarro-Perez M, Cassinelli S, Felipe A: The Potassium Channel Odyssey: Mechanisms of Traffic and Membrane Arrangement. Int J Mol Sci 2019;20:

143 Pardo LA, Stuhmer W: The roles of K(+) channels in cancer. Nat Rev Cancer 2014;14:39-48.

144 Haworth AS, Brackenbury WJ: Emerging roles for multifunctional ion channel auxiliary subunits in cancer. Cell Calcium 2019;80:125-140.

145 Wulff H, Christophersen P, Colussi P, Chandy KG, Yarov-Yarovoy V: Antibodies and venom peptides: new modalities for ion channels. Nat Rev Drug Discov 2019;18:339-357.

146 Chandy KG, Norton RS: Peptide blockers of Kv1.3 channels in T cells as therapeutics for autoimmune disease. Curr Opin Chem Biol 2017;38:97-107.

147 Szabo I, Bock J, Grassme H, Soddemann M, Wilker B, Lang F, Zoratti M, Gulbins E: Mitochondrial potassium channel Kv1.3 mediates Bax-induced apoptosis in lymphocytes. Proc Natl Acad Sci U S A 2008;105:1486114866.

148 Vennekamp J, Wulff H, Beeton C, Calabresi PA, Grissmer S, Hansel W, Chandy KG: Kv1.3-blocking 5-phenylalkoxypsoralens: a new class of immunomodulators. Mol Pharmacol 2004;65:1364-1374.

149 Zimin PI, Garic B, Bodendiek SB, Mahieux C, Wulff H, Zhorov BS: Potassium channel block by a tripartite complex of two cationophilic ligands and a potassium ion. Mol Pharmacol 2010;78:588-599.

150 Faouzi M, Starkus J, Penner R: State-dependent blocking mechanism of Kv 1.3 channels by the antimycobacterial drug clofazimine. Br J Pharmacol 2015;172:5161-5173.

151 Leanza L, Henry B, Sassi N, Zoratti M, Chandy KG, Gulbins E, Szabo I: Inhibitors of mitochondrial Kv1.3 channels induce Bax/Bak-independent death of cancer cells. EMBO Mol Med 2012;4:577-593.

152 Leanza L, Trentin L, Becker KA, Frezzato F, Zoratti M, Semenzato G, Gulbins E, Szabo I: Clofazimine, Psora-4 and PAP-1, inhibitors of the potassium channel Kv1.3, as a new and selective therapeutic strategy in chronic lymphocytic leukemia. Leukemia 2013;27:1782-1785.

153 Zaccagnino A, Manago A, Leanza L, Gontarewitz A, Linder B, Azzolini M, Biasutto L, Zoratti M, Peruzzo R, Legler K, Trauzold A, Kalthoff H, Szabo I: Tumor-reducing effect of the clinically used drug clofazimine in a SCID mouse model of pancreatic ductal adenocarcinoma. Oncotarget 2017;8:38276-38293.

154 Leanza L, Romio M, Becker KA, Azzolini M, Trentin L, Manago A, Venturini E, Zaccagnino A, Mattarei A, Carraretto L, Urbani A, Kadow S, Biasutto L, Martini V, Severin F, Peruzzo R, Trimarco V, Egberts JH, Hauser C, Visentin A, et al.: Direct Pharmacological Targeting of a Mitochondrial Ion Channel Selectively Kills Tumor Cells In vivo. Cancer Cell 2017;31:516-531.e510.

155 Venturini E, Leanza L, Azzolini M, Kadow S, Mattarei A, Weller M, Tabatabai G, Edwards MJ, Zoratti M, Paradisi C, Szabo I, Gulbins E, Becker KA: Targeting the Potassium Channel Kv1.3 Kills Glioblastoma Cells. Neurosignals 2017;25:26-38.

156 Mattarei A, Romio M, Manago A, Zoratti M, Paradisi C, Szabo I, Leanza L, Biasutto L: Novel MitochondriaTargeted Furocoumarin Derivatives as Possible Anti-Cancer Agents. Front Oncol 2018;8:122.

157 Peruzzo R, Mattarei A, Romio M, Paradisi C, Zoratti M, Szabo I, Leanza L: Regulation of Proliferation by a Mitochondrial Potassium Channel in Pancreatic Ductal Adenocarcinoma Cells. Front Oncol 2017;7:239.

158 Wulff H, Pennington M: Targeting effector memory T-cells with Kv1.3 blockers. Curr Opin Drug Discov Devel 2007;10:438-445.

159 Teisseyre A, Palko-Labuz A, Sroda-Pomianek K, Michalak K: Voltage-Gated Potassium Channel Kv1.3 as a Target in Therapy of Cancer. Front Oncol 2019;9:933.

160 Bodendiek SB, Mahieux C, Hansel W, Wulff H: 4-Phenoxybutoxy-substituted heterocycles--a structureactivity relationship study of blockers of the lymphocyte potassium channel Kv1.3. Eur J Med Chem 2009;44:1838-1852.

161 Gasiorowska J, Teisseyre A, Uryga A, Michalak K: Inhibition of Kv1.3 Channels in Human Jurkat T Cells by Xanthohumol and Isoxanthohumol. J Membr Biol 2015;248:705-711.

162 Teisseyre A, Palko-Labuz A, Uryga A, Michalak K: The Influence of 6-Prenylnaringenin and Selected Non-prenylated Flavonoids on the Activity of Kv1.3 Channels in Human Jurkat T Cells. J Membr Biol 2018;251:695-704. 


\section{Cellular Physiology Cell Physiol Biochem 2019;53(S1):11-43 \begin{tabular}{l|l|l} 
and Biol: 10.33594/000000192 2019 The Author(s). Published by \\
\hline
\end{tabular} and BiOChemistry Published online: 14 December 2019 Cell Physiol Biochem Press GmbH\&Co. KG \\ Parrasia et al.: Drugs vs Mitochondrial Channels in Cancer}

163 Baell JB, Gable RW, Harvey AJ, Toovey N, Herzog T, Hansel W, Wulff H: Khellinone derivatives as blockers of the voltage-gated potassium channel Kv1.3: synthesis and immunosuppressive activity. J Med Chem 2004;47:2326-2336.

164 Harvey AJ, Baell JB, Toovey N, Homerick D, Wulff H: A new class of blockers of the voltage-gated potassium channel Kv1.3 via modification of the 4- or 7-position of khellinone. J Med Chem 2006;49:1433-1441.

165 Cianci J, Baell JB, Flynn BL, Gable RW, Mould JA, Paul D, Harvey AJ: Synthesis and biological evaluation of chalcones as inhibitors of the voltage-gated potassium channel Kv1.3. Bioorg Med Chem Lett 2008;18:2055-2061.

166 Zhao N, Dong Q, Du LL, Fu XX, Du YM, Liao YH: Potent suppression of Kv1.3 potassium channel and IL-2 secretion by diphenyl phosphine oxide-1 in human T cells. PLoS One 2013;8:e64629.

167 Kim SE, Ahn HS, Choi BH, Jang HJ, Kim MJ, Rhie DJ, Yoon SH, Jo YH, Kim MS, Sung KW, Hahn SJ: Open channel block of A-type, kv4.3, and delayed rectifier K+ channels, Kv1.3 and Kv3.1, by sibutramine. J Pharmacol Exp Ther 2007;321:753-762.

168 Teisseyre A, Michalak K: The voltage- and time-dependent blocking effect of trifluoperazine on T lymphocyte Kv1.3 channels. Biochem Pharmacol 2003;65:551-561.

169 Zhao N, Dong Q, Fu XX, Du LL, Cheng X, Du YM, Liao YH: Acacetin blocks kv1.3 channels and inhibits human T cell activation. Cell Physiol Biochem 2014;34:1359-1372.

170 Teisseyre A, Michalak K: Genistein inhibits the activity of kv1.3 potassium channels in human T lymphocytes. J Membr Biol 2005;205:71-79.

171 Teisseyre A, Michalak K: Inhibition of the activity of human lymphocyte Kv1.3 potassium channels by resveratrol. J Membr Biol 2006;214:123-129.

172 Teisseyre A, Duarte N, Ferreira MJ, Michalak K: Influence of the multidrug transporter inhibitors on the activity of Kv1.3 voltage-gated potassium channels. J Physiol Pharmacol 2009;60:69-76.

173 Fu XX, Du LL, Zhao N, Dong Q, Liao YH, Du YM: 18beta-Glycyrrhetinic acid potently inhibits Kv1.3 potassium channels and T cell activation in human Jurkat T cells. J Ethnopharmacol 2013;148:647-654.

174 Zhao N, Dong Q, Qian C, Li S, Wu QF, Ding D, Li J, Wang BB, Guo KF, Xie JJ, Cheng X, Liao YH, Du YM: Lovastatin blocks Kv1.3 channel in human T cells: a new mechanism to explain its immunomodulatory properties. Sci Rep 2015;5:17381.

175 Kazama I, Baba A, Maruyama Y: HMG-CoA reductase inhibitors pravastatin, lovastatin and simvastatin suppress delayed rectifier K(+)-channel currents in murine thymocytes. Pharmacol Rep 2014;66:712-717.

176 Baba A, Tachi M, Maruyama Y, Kazama I: Suppressive effects of diltiazem and verapamil on delayed rectifier K(+)-channel currents in murine thymocytes. Pharmacol Rep 2015;67:959-964.

177 Bao J, Miao S, Kayser F, Kotliar AJ, Baker RK, Doss GA, Felix JP, Bugianesi RM, Slaughter RS, Kaczorowski GJ, Garcia ML, Ha SN, Castonguay L, Koo GC, Shah K, Springer MS, Staruch MJ, Parsons WH, Rupprecht KM: Potent Kv1.3 inhibitors from correolide-modification of the C18 position. Bioorg Med Chem Lett 2005;15:447-451.

178 Nguyen W: Novel Kv1.3 blockers for immunosuppression: W02012155199. Expert Opin Ther Pat 2013;23:1511-1516.

179 Wulff H: Spiro azepane-oxazolidinones as Kv1.3 potassium channel blockers: WO2010066840. Expert Opin Ther Pat 2010;20:1759-1765.

180 Gulbins E, Szabo I, Baltzer K, Lang F: Ceramide-induced inhibition of T lymphocyte voltage-gated potassium channel is mediated by tyrosine kinases. Proc Natl Acad Sci U S A 1997;94:7661-7666.

181 Bock J, Szabo I, Gamper N, Adams C, Gulbins E: Ceramide inhibits the potassium channel Kv1.3 by the formation of membrane platforms. Biochem Biophys Res Commun 2003;305:890-897.

182 Hernandez-Corbacho MJ, Salama MF, Canals D, Senkal CE, Obeid LM: Sphingolipids in mitochondria. Biochim Biophys Acta Mol Cell Biol Lipids 2017;1862:56-68.

183 Manago A, Becker KA, Carpinteiro A, Wilker B, Soddemann M, Seitz AP, Edwards MJ, Grassme H, Szabo I, Gulbins E: Pseudomonas aeruginosa pyocyanin induces neutrophil death via mitochondrial reactive oxygen species and mitochondrial acid sphingomyelinase. Antioxid Redox Signal 2015;22:1097-1110.

184 Kogot-Levin A, Saada A: Ceramide and the mitochondrial respiratory chain. Biochimie 2014;100:88-94.

185 Novgorodov SA, Voltin JR, Gooz MA, Li L, Lemasters JJ, Gudz TI: Acid sphingomyelinase promotes mitochondrial dysfunction due to glutamate-induced regulated necrosis. J Lipid Res 2018;59:312-329. 


\section{Cellular Physiology Cell Physiol Biochem 2019;53(S1):11-43 \begin{tabular}{ll|l|l|l}
\hline DOI: 10.33594/000000192 & (C)19 The Author(s). Published by
\end{tabular} and Biochemistry Published online: 14 December 2019 Cell Physiol Biochem Press GmbH\&Co. KG \\ Parrasia et al.: Drugs vs Mitochondrial Channels in Cancer}

186 Comes N, Bielanska J, Vallejo-Gracia A, Serrano-Albarras A, Marruecos L, Gomez D, Soler C, Condom E, Ramon YCS, Hernandez-Losa J, Ferreres JC, Felipe A: The voltage-dependent K(+) channels Kv1.3 and Kv1.5 in human cancer. Front Physiol 2013;4:283.

187 Leanza L, Zoratti M, Gulbins E, Szabo I: Induction of apoptosis in macrophages via Kv1.3 and Kv1.5 potassium channels. Curr Med Chem 2012;19:5394-5404.

188 Guo X, Chen W, Sun H, You Q: Kv1.5 Inhibitors for Treatment of Atrial Fibrillation: A Tradeoff between Selectivity and Non-selectivity. Curr Top Med Chem 2016;16:1843-1854.

189 Peukert S, Brendel J, Pirard B, Bruggemann A, Below P, Kleemann HW, Hemmerle H, Schmidt W: Identification, synthesis, and activity of novel blockers of the voltage-gated potassium channel Kv1.5. J Med Chem 2003;46:486-498.

190 Peukert S, Brendel J, Pirard B, Strubing C, Kleemann HW, Bohme T, Hemmerle H: Pharmacophore-based search, synthesis, and biological evaluation of anthranilic amides as novel blockers of the Kv1.5 channel. Bioorg Med Chem Lett 2004;14:2823-2827.

191 Lloyd J, Finlay HJ, Vacarro W, Hyunh T, Kover A, Bhandaru R, Yan L, Atwal K, Conder ML, Jenkins-West T, Shi H, Huang C, Li D, Sun H, Levesque P: Pyrrolidine amides of pyrazolodihydropyrimidines as potent and selective KV1.5 blockers. Bioorg Med Chem Lett 2010;20:1436-1439.

192 Decher N, Pirard B, Bundis F, Peukert S, Baringhaus KH, Busch AE, Steinmeyer K, Sanguinetti MC: Molecular basis for Kv1.5 channel block: conservation of drug binding sites among voltage-gated $\mathrm{K}+$ channels. J Biol Chem 2004;279:394-400.

193 Decher N, Kumar P, Gonzalez T, Pirard B, Sanguinetti MC: Binding site of a novel Kv1.5 blocker: a "foot in the door" against atrial fibrillation. Mol Pharmacol 2006;70:1204-1211.

194 Wu J, Ding WG, Matsuura H, Tsuji K, Zang WJ, Horie M: Inhibitory actions of the phosphatidylinositol 3-kinase inhibitor LY294002 on the human Kv1.5 channel. Br J Pharmacol 2009;156:377-387.

195 Ding WG, Tano A, Mi X, Kojima A, Seto T, Matsuura H: Identification of Verapamil Binding Sites Within Human Kv1.5 Channel Using Mutagenesis and Docking Simulation. Cell Physiol Biochem 2019;52:302-314.

196 Kojima A, Fukushima Y, Ito Y, Ding WG, Ueda R, Seto T, Kitagawa H, Matsuura H: Interactions of Propofol With Human Voltage-gated Kv1.5 Channel Determined by Docking Simulation and Mutagenesis Analyses. J Cardiovasc Pharmacol 2018;71:10-18.

197 Gong YZ, Ding WG, Wu J, Tsuji K, Horie M, Matsuura H: Cinnamyl-3, 4-dihydroxy-alpha-cyanocinnamate and nordihydroguaiaretic acid inhibit human Kv1.5 currents independently of lipoxygenase. Eur J Pharmacol 2008;600:18-25.

198 Du YM, Zhang XX, Tu DN, Zhao N, Liu YJ, Xiao H, Sanguinetti MC, Zou A, Liao YH: Molecular determinants of Kv1.5 channel block by diphenyl phosphine oxide-1. J Mol Cell Cardiol 2010;48:1111-1120.

199 Krabbendam IE, Honrath B, Culmsee C, Dolga AM: Mitochondrial Ca(2+)-activated K(+) channels and their role in cell life and death pathways. Cell Calcium 2018;69:101-111.

200 Balderas E, Zhang J, Stefani E, Toro L: Mitochondrial BKCa channel. Front Physiol 2015;6:104.

201 Stowe DF, Yang M, Heisner JS, Camara AKS: Endogenous and Agonist-induced Opening of Mitochondrial Big Versus Small Ca2+-sensitive K+ Channels on Cardiac Cell and Mitochondrial Protection. J Cardiovasc Pharmacol 2017;70:314-328.

202 Debska-Vielhaber G, Godlewski MM, Kicinska A, Skalska J, Kulawiak B, Piwonska M, Zablocki K, Kunz WS, Szewczyk A, Motyl T: Large-conductance K+ channel openers induce death of human glioma cells. J Physiol Pharmacol 2009;60:27-36.

203 Augustynek B, Koprowski P, Rotko D, Kunz WS, Szewczyk A, Kulawiak B: Mitochondrial BK Channel Openers CGS7181 and CGS7184 Exhibit Cytotoxic Properties. Int J Mol Sci 2018;19:pii:E353.

204 Bury M, Girault A, Megalizzi V, Spiegl-Kreinecker S, Mathieu V, Berger W, Evidente A, Kornienko A, Gailly $\mathrm{P}$, Vandier C, Kiss R: Ophiobolin A induces paraptosis-like cell death in human glioblastoma cells by decreasing BKCa channel activity. Cell Death Dis 2013;4:e561.

205 Hoshi T, Heinemann SH: Modulation of BK Channels by Small Endogenous Molecules and Pharmaceutical Channel Openers. Int Rev Neurobiol 2016;128:193-237.

206 Bentzen BH, Olesen SP, Ronn LC, Grunnet M: BK channel activators and their therapeutic perspectives. Front Physiol 2014;5:389.

207 McManus OB, Harris GH, Giangiacomo KM, Feigenbaum P, Reuben JP, Addy ME, Burka JF, Kaczorowski GJ, Garcia ML: An activator of calcium-dependent potassium channels isolated from a medicinal herb. Biochemistry 1993;32:6128-6133. 


\section{Cellular Physiology Cell Physiol Biochem 2019;53(S1):11-43 \begin{tabular}{l|l|l} 
and Biol: 10.33594/000000192 & C 2019 The Author(s). Published by
\end{tabular} and BIOChemistry Published online: 14 December 2019 Cell Physiol Biochem Press GmbH\&Co. KG \\ Parrasia et al.: Drugs vs Mitochondrial Channels in Cancer}

208 Yu M, Liu SL, Sun PB, Pan H, Tian CL, Zhang LH: Peptide toxins and small-molecule blockers of BK channels. Acta Pharmacol Sin 2016;37:56-66.

209 Goda AA, Siddique AB, Mohyeldin M, Ayoub NM, El Sayed KA: The Maxi-K (BK) Channel Antagonist Penitrem A as a Novel Breast Cancer-Targeted Therapeutic. Mar Drugs 2018;16:pii:E157.

210 Sallam AA, Ayoub NM, Foudah AI, Gissendanner CR, Meyer SA, El Sayed KA: Indole diterpene alkaloids as novel inhibitors of the Wnt/beta-catenin pathway in breast cancer cells. Eur J Med Chem 2013;70:594-606.

211 D'Alessandro G, Limatola C, Catalano M: Functional Roles of the Ca2+-activated K+ Channel, KCa3.1, in Brain Tumors. Curr Neuropharmacol 2018;16:636-643.

212 Catacuzzeno L, Franciolini F: Role of KCa3.1 Channels in Modulating Ca(2+) Oscillations during Glioblastoma Cell Migration and Invasion. Int J Mol Sci 2018;19:pii:E2970.

213 Mohr CJ, Gross D, Sezgin EC, Steudel FA, Ruth P, Huber SM, Lukowski R: KCa3.1 Channels Confer Radioresistance to Breast Cancer Cells. Cancers (Basel) 2019;11:pii:E1285.

214 De Marchi U, Sassi N, Fioretti B, Catacuzzeno L, Cereghetti GM, Szabo I, Zoratti M: Intermediate conductance $\mathrm{Ca} 2+$-activated potassium channel (KCa3.1) in the inner mitochondrial membrane of human colon cancer cells. Cell Calcium 2009;45:509-516.

215 Sassi N, De Marchi U, Fioretti B, Biasutto L, Gulbins E, Franciolini F, Szabo I, Zoratti M: An investigation of the occurrence and properties of the mitochondrial intermediate-conductance Ca2+-activated K+ channel mtKCa3.1. Biochim Biophys Acta 2010;1797:1260-1267.

216 Kovalenko I, Glasauer A, Schockel L, Sauter DR, Ehrmann A, Sohler F, Hagebarth A, Novak I, Christian S: Identification of KCa3.1 Channel as a Novel Regulator of Oxidative Phosphorylation in a Subset of Pancreatic Carcinoma Cell Lines. PLoS One 2016;11:e0160658.

217 Quast SA, Berger A, Buttstadt N, Friebel K, Schonherr R, Eberle J: General Sensitization of melanoma cells for TRAIL-induced apoptosis by the potassium channel inhibitor TRAM-34 depends on release of SMAC. PLoS One 2012;7:e39290.

218 Steudel FA, Mohr CJ, Stegen B, Nguyen HY, Barnert A, Steinle M, Beer-Hammer S, Koch P, Lo WY, Schroth W, Hoppe R, Brauch H, Ruth P, Huber SM, Lukowski R: SK4 channels modulate $\mathrm{Ca}(2+)$ signalling and cell cycle progression in murine breast cancer. Mol Oncol 2017;11:1172-1188.

219 Bonito B, Sauter DR, Schwab A, Djamgoz MB, Novak I: KCa3.1 (IK) modulates pancreatic cancer cell migration, invasion and proliferation: anomalous effects on TRAM-34. Pflugers Arch 2016;468:1865-1875.

220 Fioretti B, Castigli E, Micheli MR, Bova R, Sciaccaluga M, Harper A, Franciolini F, Catacuzzeno L: Expression and modulation of the intermediate- conductance Ca2+-activated $\mathrm{K}+$ channel in glioblastoma GL-15 cells. Cell Physiol Biochem 2006;18:47-56.

221 Alvarez J, Montero M, Garcia-Sancho J: High affinity inhibition of $\mathrm{Ca}(2+)$-dependent K+ channels by cytochrome P-450 inhibitors. J Biol Chem 1992;267:11789-11793.

222 Devor DC, Singh AK, Frizzell RA, Bridges RJ: Modulation of Cl- secretion by benzimidazolones. I. Direct activation of a $\mathrm{Ca}(2+)$-dependent K+ channel. Am J Physiol 1996;271:L775-784.

223 Christophersen P, Wulff H: Pharmacological gating modulation of small- and intermediate-conductance $\mathrm{Ca}(2+)$-activated K(+) channels (KCa2.x and KCa3.1). Channels (Austin) 2015;9:336-343.

224 Shim H, Brown BM, Singh L, Singh V, Fettinger JC, Yarov-Yarovoy V, Wulff H: The Trials and Tribulations of Structure Assisted Design of KCa Channel Activators. Front Pharmacol 2019;10:972.

225 Olivan-Viguera A, Valero MS, Murillo MD, Wulff H, Garcia-Otin AL, Arbones-Mainar JM, Kohler R: Novel phenolic inhibitors of small/intermediate-conductance $\mathrm{Ca}(2)(+)$-activated $\mathrm{K}(+)$ channels, KCa3.1 and KCa2.3. PLoS One 2013;8:e58614.

226 Olivan-Viguera A, Valero MS, Coleman N, Brown BM, Laria C, Murillo MD, Galvez JA, Diaz-de-Villegas MD, Wulff H, Badorrey R, Kohler R: A novel pan-negative-gating modulator of KCa2/3 channels, fluoro-dibenzoate, RA-2, inhibits endothelium-derived hyperpolarization-type relaxation in coronary artery and produces bradycardia in vivo. Mol Pharmacol 2015;87:338-348.

227 Brown BM, Pressley B, Wulff H: KCa3.1 Channel Modulators as Potential Therapeutic Compounds for Glioblastoma. Curr Neuropharmacol 2018;16:618-626.

228 Malik-Hall M, Ganellin CR, Galanakis D, Jenkinson DH: Compounds that block both intermediateconductance (IK(Ca)) and small-conductance (SK(Ca)) calcium-activated potassium channels. Br J Pharmacol 2000;129:1431-1438.

229 Castle NA, London DO, Creech C, Fajloun Z, Stocker JW, Sabatier JM: Maurotoxin: a potent inhibitor of intermediate conductance Ca2+-activated potassium channels. Mol Pharmacol 2003;63:409-418. 


\section{Cellular Physiology Cell Physiol Biochem 2019;53(S1):11-43 \begin{tabular}{l|l|l} 
and Bincl: $10.33594 / 000000192$ & 2019 The Author(s). Published by
\end{tabular} and BiOChemistry Published online: 14 December 2019 Cell Physiol Biochem Press GmbH\&Co. KG \\ Parrasia et al.: Drugs vs Mitochondrial Channels in Cancer}

230 Girault A, Haelters JP, Potier-Cartereau M, Chantome A, Jaffres PA, Bougnoux P, Joulin V, Vandier C: Targeting SKCa channels in cancer: potential new therapeutic approaches. Curr Med Chem 2012;19:697713.

231 Honrath B, Krabbendam IE, Culmsee C, Dolga AM: Small conductance Ca(2+)-activated K(+) channels in the plasma membrane, mitochondria and the ER: Pharmacology and implications in neuronal diseases. Neurochem Int 2017;109:13-23.

232 Stowe DF, Gadicherla AK, Zhou Y, Aldakkak M, Cheng Q, Kwok WM, Jiang MT, Heisner JS, Yang M, Camara AK: Protection against cardiac injury by small $\mathrm{Ca}(2+)$-sensitive $\mathrm{K}(+)$ channels identified in guinea pig cardiac inner mitochondrial membrane. Biochim Biophys Acta 2013;1828:427-442.

233 Nam YW, Orfali R, Liu T, Yu K, Cui M, Wulff H, Zhang M: Structural insights into the potency of SK channel positive modulators. Sci Rep 2017;7:17178.

234 Hougaard C, Eriksen BL, Jorgensen S, Johansen TH, Dyhring T, Madsen LS, Strobaek D, Christophersen P: Selective positive modulation of the SK3 and SK2 subtypes of small conductance Ca2+-activated K+ channels. Br J Pharmacol 2007;151:655-665.

235 Noh TK, Bang SH, Lee YJ, Cho HI, Jung MY, Kim I, Leem CH, Chang SE: The ion channel activator CyPPA inhibits melanogenesis via the GSK3beta/beta-catenin pathway. Chem Biol Interact 2019;300:1-7.

236 Liu BB, Peng YB, Zhang WJ, Zhao XX, Chen LP, Liu MS, Wang GG, Liu YJ, Shen J, Zhao P, Xue L, Yu MF, Chen W, Ma LQ Qin G, Dai J, Liu QH: NS8593 inhibits Ca(2+) permeant channels reversing mouse airway smooth muscle contraction. Life Sci 2019;238:116953.

237 Blatz AL, Magleby KL: Single apamin-blocked Ca-activated K+ channels of small conductance in cultured rat skeletal muscle. Nature 1986;323:718-720.

238 Voos P, Yazar M, Lautenschlager R, Rauh O, Moroni A, Thiel G: The small neurotoxin apamin blocks not only small conductance $\mathrm{Ca}(2+)$ activated $\mathrm{K}(+)$ channels (SK type) but also the voltage dependent Kv1.3 channel. Eur Biophys J 2017;46:517-523.

239 Simo-Vicens R, Bomholtz SH, Sorensen US, Bentzen BH: 2, 6-Bis(2-Benzimidazolyl)Pyridine (BBP) Is a Potent and Selective Inhibitor of Small Conductance Calcium-Activated Potassium (SK) Channels. Front Pharmacol 2018;9:1409.

240 Steinestel K, Eder S, Ehinger K, Schneider J, Genze F, Winkler E, Wardelmann E, Schrader AJ, Steinestel J: The small conductance calcium-activated potassium channel 3 (SK3) is a molecular target for Edelfosine to reduce the invasive potential of urothelial carcinoma cells. Tumour Biol 2016;37:6275-6283.

241 Niemeyer MI, Cid LP, Gonzalez W, Sepulveda FV: Gating, Regulation, and Structure in K2P K+ Channels: In Varietate Concordia? Mol Pharmacol 2016;90:309-317.

242 Sepulveda FV, Pablo Cid L, Teulon J, Niemeyer MI: Molecular aspects of structure, gating, and physiology of pH-sensitive background K2P and Kir K+-transport channels. Physiol Rev 2015;95:179-217.

243 Zavala WD, Foscolo MR, Kunda PE, Cavicchia JC, Acosta CG: Changes in the expression of the potassium channels TASK1, TASK3 and TRESK in a rat model of oral squamous cell carcinoma and their relation to malignancy. Arch Oral Biol 2019;100:75-85.

244 Zuniga R, Valenzuela C, Concha G, Brown N, Zuniga L: TASK-3 Downregulation Triggers Cellular Senescence and Growth Inhibition in Breast Cancer Cell Lines. Int J Mol Sci 2018;19:pii:E1033.

245 Bittner S, Budde T, Wiendl H, Meuth SG: From the background to the spotlight: TASK channels in pathological conditions. Brain Pathol 2010;20:999-1009.

246 Rusznak Z, Bakondi G, Kosztka L, Pocsai K, Dienes B, Fodor J, Telek A, Gonczi M, Szucs G, Csernoch L: Mitochondrial expression of the two-pore domain TASK-3 channels in malignantly transformed and nonmalignant human cells. Virchows Arch 2008;452:415-426.

247 Toczylowska-Maminska R, Olszewska A, Laskowski M, Bednarczyk P, Skowronek K, Szewczyk A: Potassium channel in the mitochondria of human keratinocytes. J Invest Dermatol 2014;134:764-772.

248 Kosztka L, Rusznak Z, Nagy D, Nagy Z, Fodor J, Szucs G, Telek A, Gonczi M, Ruzsnavszky O, Szentandrassy $\mathrm{N}$, Csernoch L: Inhibition of TASK-3 (KCNK9) channel biosynthesis changes cell morphology and decreases both DNA content and mitochondrial function of melanoma cells maintained in cell culture. Melanoma Res 2011;21:308-322.

249 Nagy D, Gonczi M, Dienes B, Szoor A, Fodor J, Nagy Z, Toth A, Fodor T, Bai P, Szucs G, Rusznak Z, Csernoch L: Silencing the KCNK9 potassium channel (TASK-3) gene disturbs mitochondrial function, causes mitochondrial depolarization, and induces apoptosis of human melanoma cells. Arch Dermatol Res 2014;306:885-902. 


\section{Cellular Physiology Cell Physiol Biochem 2019;53(S1):11-43 \begin{tabular}{l|l|l|l|l}
\hline DOI: 10.33594/000000192 & (O) 2019 The Author(s). Published by
\end{tabular} and Biochemistry Published online: 14 December 2019 Cell Physiol Biochem Press GmbH\&Co. KG \\ Parrasia et al.: Drugs vs Mitochondrial Channels in Cancer}

250 Bedoya M, Rinne S, Kiper AK, Decher N, Gonzalez W, Ramirez D: TASK Channels Pharmacology: New Challenges in Drug Design. J Med Chem 2019; DOI:10.1021/acs.jmedchem.9b00248.

251 Sterbuleac D: Molecular determinants of chemical modulation of two-pore domain potassium channels. Chem Biol Drug Des 2019;94:1596-1614.

252 Ma L, Zhang X, Zhou M, Chen H: Acid-sensitive TWIK and TASK two-pore domain potassium channels change ion selectivity and become permeable to sodium in extracellular acidification. J Biol Chem 2012;287:37145-37153.

253 Clarke CE, Veale EL, Green PJ, Meadows HJ, Mathie A: Selective block of the human 2-P domain potassium channel, TASK-3, and the native leak potassium current, IKSO, by zinc. J Physiol 2004;560:51-62.

254 Czirjak G, Enyedi P: Formation of functional heterodimers between the TASK-1 and TASK-3 two-pore domain potassium channel subunits. J Biol Chem 2002;277:5426-5432.

255 Czirjak G, Enyedi P: Ruthenium red inhibits TASK-3 potassium channel by interconnecting glutamate 70 of the two subunits. Mol Pharmacol 2003;63:646-652.

256 Maingret F, Patel AJ, Lazdunski M, Honore E: The endocannabinoid anandamide is a direct and selective blocker of the background K(+) channel TASK-1. Embo j 2001;20:47-54.

257 Luethy A, Boghosian JD, Srikantha R, Cotten JF: Halogenated Ether, Alcohol, and Alkane Anesthetics Activate TASK-3 Tandem Pore Potassium Channels Likely through a Common Mechanism. Mol Pharmacol 2017;91:620-629.

258 Chokshi RH, Larsen AT, Bhayana B, Cotten JF: Breathing Stimulant Compounds Inhibit TASK-3 Potassium Channel Function Likely by Binding at a Common Site in the Channel Pore. Mol Pharmacol 2015;88:926934.

259 O'Donohoe PB, Huskens N, Turner PJ, Pandit JJ, Buckler KJ: A1899, PK-THPP, ML365, and Doxapram inhibit endogenous TASK channels and excite calcium signaling in carotid body type- 1 cells. Physiol Rep 2018;6:e13876.

260 Cunningham KP, MacIntyre DE, Mathie A, Veale EL: Effects of the ventilatory stimulant, doxapram on human TASK-3 (KCNK9, K2P9.1) channels and TASK-1 (KCNK3, K2P3.1) channels. Acta Physiol (Oxf) 2019; DOI:10.1111/apha.13361e13361.

261 Noriega-Navarro R, Lopez-Charcas O, Hernandez-Enriquez B, Reyes-Gutierrez PE, Martinez R, Landa A, Moran J, Gomora JC, Garcia-Valdes J: Novel TASK channels inhibitors derived from dihydropyrrolo [2, 1-a] isoquinoline. Neuropharmacology 2014;79:28-36.

262 Wilke BU, Lindner M, Greifenberg L, Albus A, Kronimus Y, Bunemann M, Leitner MG, Oliver D: Diacylglycerol mediates regulation of TASK potassium channels by Gq-coupled receptors. Nat Commun 2014;5:5540.

263 Coburn CA, Luo Y, Cui M, Wang J, Soll R, Dong J, Hu B, Lyon MA, Santarelli VP, Kraus RL, Gregan Y, Wang Y, Fox SV, Binns J, Doran SM, Reiss DR, Tannenbaum PL, Gotter AL, Meinke PT, Renger JJ: Discovery of a pharmacologically active antagonist of the two-pore-domain potassium channel K2P9.1 (TASK-3). ChemMedChem 2012;7:123-133.

264 Ramirez D, Bedoya M, Kiper AK, Rinne S, Morales-Navarro S, Hernandez-Rodriguez EW, Sepulveda FV, Decher N, Gonzalez W: Structure/Activity Analysis of TASK-3 Channel Antagonists Based on a 5, 6,7, 8 tetrahydropyrido [4, 3-d]pyrimidine. Int J Mol Sci 2019;20:pii:E2252.

265 Ramirez D, Concha G, Arevalo B, Prent-Penaloza L, Zuniga L, Kiper AK, Rinne S, Reyes-Parada M, Decher N, Gonzalez W, Caballero J: Discovery of Novel TASK-3 Channel Blockers Using a Pharmacophore-Based Virtual Screening. Int J Mol Sci 2019;20:pii:E4014.

266 Streit AK, Netter MF, Kempf F, Walecki M, Rinne S, Bollepalli MK, Preisig-Muller R, Renigunta V, Daut J, Baukrowitz T, Sansom MS, Stansfeld PJ, Decher N: A specific two-pore domain potassium channel blocker defines the structure of the TASK-1 open pore. J Biol Chem 2011;286:13977-13984.

267 Ramirez D, Arevalo B, Martinez G, Rinne S, Sepulveda FV, Decher N, Gonzalez W: Side Fenestrations Provide an "Anchor" for a Stable Binding of A1899 to the Pore of TASK-1 Potassium Channels. Mol Pharm 2017;14:2197-2208.

268 Flaherty DP, Simpson DS, Miller M, Maki BE, Zou B, Shi J, Wu M, McManus OB, Aube J, Li M, Golden JE: Potent and selective inhibitors of the TASK-1 potassium channel through chemical optimization of a bisamide scaffold. Bioorg Med Chem Lett 2014;24:3968-3973. 


\section{Cellular Physiology Cell Physiol Biochem 2019;53(S1):11-43 \begin{tabular}{ll|l} 
DOI: 10.33594/000000192 & (C) 2019 The Author(s). Published by
\end{tabular} and Biochemistry Published online: 14 December 2019 Cell Physiol Biochem Press GmbH\&Co. KG \\ Parrasia et al.: Drugs vs Mitochondrial Channels in Cancer}

269 Miller MR, Zou B, Shi J, Flaherty DP, Simpson DS, Yao T, Maki BE, Day VW, Douglas JT, Wu M, McManus OB, Golden JE, Aube J, Li M: Development of a Selective Chemical Inhibitor for the Two-Pore Potassium Channel, KCNK9; in: Probe Reports from the NIH Molecular Libraries Program. Bethesda (MD), National Center for Biotechnology Information (US), 2010 [Internet]. URL: https://www.ncbi.nlm.nih.gov/books/ NBK133427/.

270 Tian F, Qiu Y, Lan X, Li M, Yang H, Gao Z: A Small-Molecule Compound Selectively Activates K2P Channel TASK-3 by Acting at Two Distant Clusters of Residues. Mol Pharmacol 2019;96:26-35.

271 Wright PD, Veale EL, McCoull D, Tickle DC, Large JM, Ococks E, Gothard G, Kettleborough C, Mathie A, Jerman J: Terbinafine is a novel and selective activator of the two-pore domain potassium channel TASK3. Biochem Biophys Res Commun 2017;493:444-450.

272 Schewe M, Sun H, Mert U, Mackenzie A, Pike ACW, Schulz F, Constantin C, Vowinkel KS, Conrad LJ, Kiper AK, Gonzalez W, Musinszki M, Tegtmeier M, Pryde DC, Belabed H, Nazare M, de Groot BL, Decher N, Fakler B, Carpenter EP, Tucker SJ, Baukrowitz T: A pharmacological master key mechanism that unlocks the selectivity filter gate in $\mathrm{K}(+)$ channels. Science 2019;363:875-880.

273 Shoshan-Barmatz V, De Pinto V, Zweckstetter M, Raviv Z, Keinan N, Arbel N: VDAC, a multi-functional mitochondrial protein regulating cell life and death. Mol Aspects Med 2010;31:227-285.

274 Magri A, Reina S, De Pinto V: VDAC1 as Pharmacological Target in Cancer and Neurodegeneration: Focus on Its Role in Apoptosis. Front Chem 2018;6:108.

275 Messina A, Reina S, Guarino F, De Pinto V: VDAC isoforms in mammals. Biochim Biophys Acta 2012;1818:1466-1476.

276 Shoshan-Barmatz V, Israelson A: The voltage-dependent anion channel in endoplasmic/sarcoplasmic reticulum: characterization, modulation and possible function. J Membr Biol 2005;204:57-66.

277 Reymann S, Haase W, Krick W, Burckhardt G, Thinnes FP: Endosomes: another extra-mitochondrial location of type-1 porin/voltage-dependent anion-selective channels. Pflugers Arch 1998;436:478-480.

278 Thinnes FP: Evidence for extra-mitochondrial localization of the VDAC/porin channel in eucaryotic cells. J Bioenerg Biomembr 1992;24:71-75.

279 Bathori G, Parolini I, Tombola F, Szabo I, Messina A, Oliva M, De Pinto V, Lisanti M, Sargiacomo M, Zoratti M: Porin is present in the plasma membrane where it is concentrated in caveolae and caveolae-related domains. J Biol Chem 1999;274:29607-29612.

280 De Pinto V, Messina A, Lane DJ, Lawen A: Voltage-dependent anion-selective channel (VDAC) in the plasma membrane. FEBS Lett 2010;584:1793-1799.

281 Shoshan-Barmatz V, Krelin Y, Shteinfer-Kuzmine A: VDAC1 functions in $\mathrm{Ca}(2+)$ homeostasis and cell life and death in health and disease. Cell Calcium 2018;69:81-100.

282 Rostovtseva T, Colombini M: VDAC channels mediate and gate the flow of ATP: implications for the regulation of mitochondrial function. Biophys J 1997;72:1954-1962.

283 Hodge T, Colombini M: Regulation of metabolite flux through voltage-gating of VDAC channels. J Membr Biol 1997;157:271-279.

284 Shoshan-Barmatz V, Pittala S, Mizrachi D: VDAC1 and the TSPO: Expression, Interactions, and Associated Functions in Health and Disease States. Int J Mol Sci 2019;20:pii:E3348.

285 Doan KN, Ellenrieder L, Becker T: Mitochondrial porin links protein biogenesis to metabolism. Curr Genet 2019;65:899-903.

286 Shoshan-Barmatz V, Nahon-Crystal E, Shteinfer-Kuzmine A, Gupta R: VDAC1, mitochondrial dysfunction, and Alzheimer's disease. Pharmacol Res 2018;131:87-101.

287 Shoshan-Barmatz V, Krelin Y, Chen Q: VDAC1 as a Player in Mitochondria-Mediated Apoptosis and Target for Modulating Apoptosis. Curr Med Chem 2017;24:4435-4446.

288 Tsujimoto Y, Shimizu S: VDAC regulation by the Bcl-2 family of proteins. Cell Death Differ 2000;7:11741181.

289 Shoshan-Barmatz V, Mizrachi D, Keinan N: Oligomerization of the mitochondrial protein VDAC1: from structure to function and cancer therapy. Prog Mol Biol Transl Sci 2013;117:303-334.

290 Shoshan-Barmatz V, Krelin Y, Shteinfer-Kuzmine A, Arif T: Voltage-Dependent Anion Channel 1 As an Emerging Drug Target for Novel Anti-Cancer Therapeutics. Front Oncol 2017;7:154.

291 Shoshan-Barmatz V, Ben-Hail D, Admoni L, Krelin Y, Tripathi SS: The mitochondrial voltage-dependent anion channel 1 in tumor cells. Biochim Biophys Acta 2015;1848:2547-2575. 


\section{Cellular Physiology Cell Physiol Biochem 2019;53(S1):11-43 \begin{tabular}{l|l|l} 
and Biol: 10.33594/000000192 & (c)19 The Author(s). Published by
\end{tabular} and BiOChemistry Published online: 14 December 2019 Cell Physiol Biochem Press GmbH\&Co. KG \\ Parrasia et al.: Drugs vs Mitochondrial Channels in Cancer}

292 Reina S, De Pinto V: Anti-Cancer Compounds Targeted to VDAC: Potential and Perspectives. Curr Med Chem 2017;24:4447-4469.

293 Mazure NM: VDAC in cancer. Biochim Biophys Acta Bioenerg 2017;1858:665-673.

294 Nakashima RA: Hexokinase-binding properties of the mitochondrial VDAC protein: inhibition by DCCD and location of putative DCCD-binding sites. J Bioenerg Biomembr 1989;21:461-470.

295 Azoulay-Zohar H, Israelson A, Abu-Hamad S, Shoshan-Barmatz V: In self-defence: hexokinase promotes voltage-dependent anion channel closure and prevents mitochondria-mediated apoptotic cell death. Biochem J 2004;377:347-355.

296 Rostovtseva TK, Sheldon KL, Hassanzadeh E, Monge C, Saks V, Bezrukov SM, Sackett DL: Tubulin binding blocks mitochondrial voltage-dependent anion channel and regulates respiration. Proc Natl Acad Sci U S A 2008;105:18746-18751.

297 Sheldon KL, Maldonado EN, Lemasters JJ, Rostovtseva TK, Bezrukov SM: Phosphorylation of voltagedependent anion channel by serine/threonine kinases governs its interaction with tubulin. PLoS One 2011;6:e25539.

298 Rostovtseva TK, Bezrukov SM: VDAC inhibition by tubulin and its physiological implications. Biochim Biophys Acta 2012;1818:1526-1535.

299 Puurand M, Tepp K, Timohhina N, Aid J, Shevchuk I, Chekulayev V, Kaambre T: Tubulin betaII and betaIII Isoforms as the Regulators of VDAC Channel Permeability in Health and Disease. Cells 2019;8:pii:E239.

300 Goldin N, Arzoine L, Heyfets A, Israelson A, Zaslavsky Z, Bravman T, Bronner V, Notcovich A, ShoshanBarmatz V, Flescher E: Methyl jasmonate binds to and detaches mitochondria-bound hexokinase. Oncogene 2008;27:4636-4643.

301 Arzoine L, Zilberberg N, Ben-Romano R, Shoshan-Barmatz V: Voltage-dependent anion channel 1-based peptides interact with hexokinase to prevent its anti-apoptotic activity. J Biol Chem 2009;284:3946-3955.

302 Prezma T, Shteinfer A, Admoni L, Raviv Z, Sela I, Levi I, Shoshan-Barmatz V: VDAC1-based peptides: novel pro-apoptotic agents and potential therapeutics for B-cell chronic lymphocytic leukemia. Cell Death Dis 2013;4:e809.

303 Shteinfer-Kuzmine A, Amsalem Z, Arif T, Zooravlov A, Shoshan-Barmatz V: Selective induction of cancer cell death by VDAC1-based peptides and their potential use in cancer therapy. Mol Oncol 2018;12:1077-1103.

304 Haridas V, Li X, Mizumachi T, Higuchi M, Lemeshko VV, Colombini M, Gutterman JU: Avicins, a novel plant-derived metabolite lowers energy metabolism in tumor cells by targeting the outer mitochondrial membrane. Mitochondrion 2007;7:234-240.

305 Tewari D, Majumdar D, Vallabhaneni S, Bera AK: Aspirin induces cell death by directly modulating mitochondrial voltage-dependent anion channel (VDAC). Sci Rep 2017;7:45184.

306 DeHart DN, Lemasters JJ, Maldonado EN: Erastin-Like Anti-Warburg Agents Prevent Mitochondrial Depolarization Induced by Free Tubulin and Decrease Lactate Formation in Cancer Cells. SLAS Discov 2018;23:23-33.

307 Maldonado EN, Sheldon KL, DeHart DN, Patnaik J, Manevich Y, Townsend DM, Bezrukov SM, Rostovtseva TK, Lemasters JJ: Voltage-dependent anion channels modulate mitochondrial metabolism in cancer cells: regulation by free tubulin and erastin. J Biol Chem 2013;288:11920-11929.

308 Nahon E, Israelson A, Abu-Hamad S, Varda SB: Fluoxetine (Prozac) interaction with the mitochondrial voltage-dependent anion channel and protection against apoptotic cell death. FEBS Lett 2005;579:51055110.

309 Tan W, Loke YH, Stein CA, Miller P, Colombini M: Phosphorothioate oligonucleotides block the VDAC channel. Biophys J 2007;93:1184-1191.

310 Ben-Hail D, Shoshan-Barmatz V: VDAC1-interacting anion transport inhibitors inhibit VDAC1 oligomerization and apoptosis. Biochim Biophys Acta 2016;1863:1612-1623.

311 Benitez-Rangel E, Lopez-Mendez MC, Garcia L, Guerrero-Hernandez A: DIDS (4, 4'-Diisothiocyanatostilbene-2, 2'-disulfonate) directly inhibits caspase activity in HeLa cell lysates. Cell Death Discov 2015;1:15037.

312 De Pinto V, Guarino F, Guarnera A, Messina A, Reina S, Tomasello FM, Palermo V, Mazzoni C: Characterization of human VDAC isoforms: a peculiar function for VDAC3? Biochim Biophys Acta 2010;1797:1268-1275.

313 Maurya SR, Mahalakshmi R: VDAC-2: Mitochondrial outer membrane regulator masquerading as a channel? FEBS J 2016;283:1831-1836. 
314 Gattin Z, Schneider R, Laukat Y, Giller K, Maier E, Zweckstetter M, Griesinger C, Benz R, Becker S, Lange A: Solid-state NMR, electrophysiology and molecular dynamics characterization of human VDAC2. J Biomol NMR 2015;61:311-320.

315 Magri A, Karachitos A, Di Rosa MC, Reina S, Conti Nibali S, Messina A, Kmita H, De Pinto V: Recombinant yeast VDAC2: a comparison of electrophysiological features with the native form. FEBS Open Bio 2019;9:1184-1193.

316 Okazaki M, Kurabayashi K, Asanuma M, Saito Y, Dodo K, Sodeoka M: VDAC3 gating is activated by suppression of disulfide-bond formation between the N-terminal region and the bottom of the pore. Biochim Biophys Acta 2015;1848:3188-3196.

317 Naghdi S, Hajnoczky G: VDAC2-specific cellular functions and the underlying structure. Biochim Biophys Acta 2016;1863:2503-2514.

318 Saletti R, Reina S, Pittala MG, Belfiore R, Cunsolo V, Messina A, De Pinto V, Foti S: High resolution mass spectrometry characterization of the oxidation pattern of methionine and cysteine residues in rat liver mitochondria voltage-dependent anion selective channel 3 (VDAC3). Biochim Biophys Acta Biomembr 2017;1859:301-311.

319 Caterino M, Ruoppolo M, Mandola A, Costanzo M, Orru S, Imperlini E: Protein-protein interaction networks as a new perspective to evaluate distinct functional roles of voltage-dependent anion channel isoforms. Mol Biosyst 2017;13:2466-2476.

320 Cheng EH, Sheiko TV, Fisher JK, Craigen WJ, Korsmeyer SJ: VDAC2 inhibits BAK activation and mitochondrial apoptosis. Science 2003;301:513-517.

321 Plotz M, Gillissen B, Hossini AM, Daniel PT, Eberle J: Disruption of the VDAC2-Bak interaction by Bcl-x(S) mediates efficient induction of apoptosis in melanoma cells. Cell Death Differ 2012;19:1928-1938.

322 Naghdi S, Varnai P, Hajnoczky G: Motifs of VDAC2 required for mitochondrial Bak import and tBid-induced apoptosis. Proc Natl Acad Sci U S A 2015;112:E5590-5599.

323 van Delft MF, Chappaz S, Khakham Y, Bui CT, Debrincat MA, Lowes KN, Brouwer JM, Grohmann C, Sharp PP, Dagley LF, Li L, McArthur K, Luo MX, Chin HS, Fairlie WD, Lee EF, Segal D, Duflocq S, Lessene R, et al.: A small molecule interacts with VDAC2 to block mouse BAK-driven apoptosis. Nat Chem Biol 2019;10.1038/ s41589-019-0365-8

324 Lauterwasser J, Todt F, Zerbes RM, Nguyen TN, Craigen W, Lazarou M, van der Laan M, Edlich F: The porin VDAC2 is the mitochondrial platform for Bax retrotranslocation. Sci Rep 2016;6:32994.

325 Chin HS, Li MX, Tan IKL, Ninnis RL, Reljic B, Scicluna K, Dagley LF, Sandow JJ, Kelly GL, Samson AL, Chappaz S, Khaw SL, Chang C, Morokoff A, Brinkmann K, Webb A, Hockings C, Hall CM, Kueh AJ, Ryan MT, et al.: VDAC2 enables BAX to mediate apoptosis and limit tumor development. Nat Commun 2018;9:4976.

326 Han JH, Park J, Myung SH, Lee SH, Kim HY, Kim KS, Seo YW, Kim TH: Noxa mitochondrial targeting domain induces necrosis via VDAC2 and mitochondrial catastrophe. Cell Death Dis 2019;10:519.

327 Tanno M, Kuno A, Ishikawa S, Miki T, Kouzu H, Yano T, Murase H, Tobisawa T, Ogasawara M, Horio Y, Miura T: Translocation of glycogen synthase kinase-3beta (GSK-3beta), a trigger of permeability transition, is kinase activity-dependent and mediated by interaction with voltage-dependent anion channel 2 (VDAC2). J Biol Chem 2014;289:29285-29296.

328 Dadsena S, Bockelmann S, Mina JGM, Hassan DG, Korneev S, Razzera G, Jahn H, Niekamp P, Muller D, Schneider M, Tafesse FG, Marrink SJ, Melo MN, Holthuis JCM: Ceramides bind VDAC2 to trigger mitochondrial apoptosis. Nat Commun 2019;10:1832.

329 Dadsena S, Hassan DG, Holthuis JCM: Unraveling the molecular principles by which ceramides commit cells to death. Cell Stress 2019;3:280-283.

330 Aono Y, Horinaka M, Iizumi Y, Watanabe M, Taniguchi T, Yasuda S, Sakai T: Sulindac sulfone inhibits the mTORC1 pathway in colon cancer cells by directly targeting voltage-dependent anion channel 1 and 2 . Biochem Biophys Res Commun 2018;505:1203-1210.

331 Zhou C, Pan W, Wang XP, Chen TS: Artesunate induces apoptosis via a Bak-mediated caspase-independent intrinsic pathway in human lung adenocarcinoma cells. J Cell Physiol 2012;227:3778-3786.

332 Reina S, Guarino F, Magri A, De Pinto V: VDAC3 As a Potential Marker of Mitochondrial Status Is Involved in Cancer and Pathology. Front Oncol 2016;6:264.

333 Argenzio E, Moolenaar WH: Emerging biological roles of Cl- intracellular channel proteins. J Cell Sci 2016;129:4165-4174. 


\section{Cellular Physiology Cell Physiol Biochem 2019;53(S1):11-43 \begin{tabular}{ll|l|l|l} 
DOI: 10.33594/000000192 & (O) 2019 The Author(s). Published by
\end{tabular} and Biochemistry Published online: 14 December 2019 Cell Physiol Biochem Press GmbH\&Co. KG \\ Parrasia et al.: Drugs vs Mitochondrial Channels in Cancer}

334 Gururaja Rao S, Ponnalagu D, Sukur S, Singh H, Sanghvi S, Mei Y, Jin DJ, Singh H: Identification and Characterization of a Bacterial Homolog of Chloride Intracellular Channel (CLIC) Protein. Sci Rep 2017;7:8500.

335 Ponnalagu D, Gururaja Rao S, Farber J, Xin W, Hussain AT, Shah K, Tanda S, Berryman M, Edwards JC, Singh $\mathrm{H}$ : Molecular identity of cardiac mitochondrial chloride intracellular channel proteins. Mitochondrion 2016;27:6-14.

336 Arnould T, Mercy L, Houbion A, Vankoningsloo S, Renard P, Pascal T, Ninane N, Demazy C, Raes M: mtCLIC is up-regulated and maintains a mitochondrial membrane potential in mtDNA-depleted L929 cells. Faseb j 2003;17:2145-2147.

337 Suh KS, Mutoh M, Gerdes M, Yuspa SH: CLIC4, an intracellular chloride channel protein, is a novel molecular target for cancer therapy. J Investig Dermatol Symp Proc 2005;10:105-109.

338 Saberbaghi T, Wong R, Rutka JT, Wang GL, Feng ZP, Sun HS: Role of Cl(-) channels in primary brain tumour. Cell Calcium 2019;81:1-11.

339 Nesiu A, Cimpean AM, Ceausu RA, Adile A, Ioiart I, Porta C, Mazzanti M, Camerota TC, Raica M: Intracellular Chloride Ion Channel Protein-1 Expression in Clear Cell Renal Cell Carcinoma. Cancer Genomics Proteomics 2019;16:299-307.

340 Peretti M, Angelini M, Savalli N, Florio T, Yuspa SH, Mazzanti M: Chloride channels in cancer: Focus on chloride intracellular channel 1 and 4 (CLIC1 AND CLIC4) proteins in tumor development and as novel therapeutic targets. Biochim Biophys Acta 2015;1848:2523-2531.

341 Setti M, Savalli N, Osti D, Richichi C, Angelini M, Brescia P, Fornasari L, Carro MS, Mazzanti M, Pelicci G: Functional role of CLIC1 ion channel in glioblastoma-derived stem/progenitor cells. J Natl Cancer Inst 2013;105:1644-1655.

342 Gritti M, Wurth R, Angelini M, Barbieri F, Peretti M, Pizzi E, Pattarozzi A, Carra E, Sirito R, Daga A, Curmi PM, Mazzanti M, Florio T: Metformin repositioning as antitumoral agent: selective antiproliferative effects in human glioblastoma stem cells, via inhibition of CLIC1-mediated ion current. Oncotarget 2014;5:1125211268.

343 Barbieri F, Verduci I, Carlini V, Zona G, Pagano A, Mazzanti M, Florio T: Repurposed Biguanide Drugs in Glioblastoma Exert Antiproliferative Effects via the Inhibition of Intracellular Chloride Channel 1 Activity. Front Oncol 2019;9:135.

344 Tasiopoulou V, Magouliotis D, Solenov EI, Vavougios G, Molyvdas PA, Gourgoulianis KI, Hatzoglou C, Zarogiannis SG: Transcriptional over-expression of chloride intracellular channels 3 and 4 in malignant pleural mesothelioma. Comput Biol Chem 2015;59 Pt A:111-116.

345 Suh KS, Malik M, Shukla A, Ryscavage A, Wright L, Jividen K, Crutchley JM, Dumont RA, Fernandez-Salas E, Webster JD, Simpson RM, Yuspa SH: CLIC4 is a tumor suppressor for cutaneous squamous cell cancer. Carcinogenesis 2012;33:986-995.

346 Yao Q Qu X, Yang Q Wei M, Kong B: CLIC4 mediates TGF-beta1-induced fibroblast-to-myofibroblast transdifferentiation in ovarian cancer. Oncol Rep 2009;22:541-548.

347 Xu Y, Kang J, Yuan Z, Li H, Su J, Li Y, Kong X, Zhang H, Wang W, Sun L: Suppression of CLIC4/mtCLIC enhances hydrogen peroxide-induced apoptosis in C6 glioma cells. Oncol Rep 2013;29:1483-1491.

348 Zhao W, Lu M, Zhang Q: Chloride intracellular channel 1 regulates migration and invasion in gastric cancer by triggering the ROS-mediated p38 MAPK signaling pathway. Mol Med Rep 2015;12:8041-8047.

349 Colombini M: A candidate for the permeability pathway of the outer mitochondrial membrane. Nature 1979;279:643-645.

350 Schein SJ, Colombini M, Finkelstein A: Reconstitution in planar lipid bilayers of a voltage-dependent anionselective channel obtained from paramecium mitochondria. J Membr Biol 1976;30:99-120.

351 Arif T, Krelin Y, Nakdimon I, Benharroch D, Paul A, Dadon-Klein D, Shoshan-Barmatz V: VDAC1 is a molecular target in glioblastoma, with its depletion leading to reprogrammed metabolism and reversed oncogenic properties. Neuro Oncol 2017;19:951-964.

352 Shimizu S, Konishi A, Kodama T, Tsujimoto Y: BH4 domain of antiapoptotic Bcl-2 family members closes voltage-dependent anion channel and inhibits apoptotic mitochondrial changes and cell death. Proc Natl Acad Sci U S A 2000;97:3100-3105.

353 Tajeddine N, Galluzzi L, Kepp O, Hangen E, Morselli E, Senovilla L, Araujo N, Pinna G, Larochette N, Zamzami N, Modjtahedi N, Harel-Bellan A, Kroemer G: Hierarchical involvement of Bak, VDAC1 and Bax in cisplatininduced cell death. Oncogene 2008;27:4221-4232. 


\section{Cellular Physiology Cell Physiol Biochem 2019;53(S1):11-43 \begin{tabular}{l|l|l} 
and Biol: 10.33594/000000192 & (c)19 The Author(s). Published by
\end{tabular} and BiOChemistry Published online: 14 December 2019 Cell Physiol Biochem Press GmbH\&Co. KG \\ Parrasia et al.: Drugs vs Mitochondrial Channels in Cancer}

354 Tomasello F, Messina A, Lartigue L, Schembri L, Medina C, Reina S, Thoraval D, Crouzet M, Ichas F, De Pinto V, De Giorgi F: Outer membrane VDAC1 controls permeability transition of the inner mitochondrial membrane in cellulo during stress-induced apoptosis. Cell Res 2009;19:1363-1376.

355 Blachly-Dyson E, Baldini A, Litt M, McCabe ER, Forte M: Human genes encoding the voltage-dependent anion channel (VDAC) of the outer mitochondrial membrane: mapping and identification of two new isoforms. Genomics 1994;20:62-67.

356 Paggio A, Checchetto V, Campo A, Menabo R, Di Marco G, Di Lisa F, Szabo I, Rizzuto R, De Stefani D: Identification of an ATP-sensitive potassium channel in mitochondria. Nature 2019;572:609-613.

357 Siemen D, Ziemer M: What is the nature of the mitochondrial permeability transition pore and what is it not? IUBMB Life 2013;65:255-262.

358 Singh H, Lu R, Bopassa JC, Meredith AL, Stefani E, Toro L: MitoBK(Ca) is encoded by the Kcnma1 gene, and a splicing sequence defines its mitochondrial location. Proc Natl Acad Sci U S A 2013;110:10836-10841.

359 Skalska J, Piwonska M, Wyroba E, Surmacz L, Wieczorek R, Koszela-Piotrowska I, Zielinska J, Bednarczyk P, Dolowy K, Wilczynski GM, Szewczyk A, Kunz WS: A novel potassium channel in skeletal muscle mitochondria. Biochim Biophys Acta 2008;1777:651-659.

360 Lukas K, Efe CS, Marco S, Franziska E, Stephan MH: KCa3.1 Channels and Glioblastoma: In vitro Studies. Current Neuropharmacology 2018;16:627-635.

361 Ruggieri P, Mangino G, Fioretti B, Catacuzzeno L, Puca R, Ponti D, Miscusi M, Franciolini F, Ragona G, Calogero A: The inhibition of KCa3.1 channels activity reduces cell motility in glioblastoma derived cancer stem cells. PLoS One 2012;7:e47825.

362 De Stefani D, Raffaello A, Teardo E, Szabò I, Rizzuto R: A forty-kilodalton protein of the inner membrane is the mitochondrial calcium uniporter. Nature 2011;476:336-340.

363 Beutner G, Sharma VK, Giovannucci DR, Yule DI, Sheu SS: Identification of a ryanodine receptor in rat heart mitochondria. J Biol Chem 2001;276:21482-21488.

364 Kolisek M, Zsurka G, Samaj J, Weghuber J, Schweyen RJ, Schweigel M: Mrs2p is an essential component of the major electrophoretic Mg2+ influx system in mitochondria. Embo j 2003;22:1235-1244.

365 Wolf FI, Trapani V: Multidrug resistance phenotypes and MRS2 mitochondrial magnesium channel: two players from one stemness? Cancer Biol Ther 2009;8:615-617.

366 Haworth RA, Hunter DR: The Ca2+-induced membrane transition in mitochondria. II. Nature of the Ca2+ trigger site. Arch Biochem Biophys 1979;195:460-467.

367 Haworth RA, Hunter DR: Allosteric inhibition of the Ca2+-activated hydrophilic channel of the mitochondrial inner membrane by nucleotides. J Membr Biol 1980;54:231-236.

368 Haworth RA, Hunter DR: Control of the mitochondrial permeability transition pore by high-affinity ADP binding at the ADP/ATP translocase in permeabilized mitochondria. J Bioenerg Biomembr 2000;32:91-96.

369 Marchi S, Vitto VAM, Patergnani S, Pinton P: High mitochondrial Ca(2+) content increases cancer cell proliferation upon inhibition of mitochondrial permeability transition pore (mPTP). Cell Cycle 2019;18:914-916.

370 Zhang R, Li G, Zhang Q, Tang Q Huang J, Hu C, Liu Y, Wang Q, Liu W, Gao N, Zhou S: Hirsutine induces mPTPdependent apoptosis through ROCK1/PTEN/PI3K/GSK3beta pathway in human lung cancer cells. Cell Death Dis 2018;9:598.

371 Szabo I, Bock J, Jekle A, Soddemann M, Adams C, Lang F, Zoratti M, Gulbins E: A novel potassium channel in lymphocyte mitochondria. J Biol Chem 2005;280:12790-12798.

372 Gulbins E, Sassi N, Grassme H, Zoratti M, Szabo I: Role of Kv1.3 mitochondrial potassium channel in apoptotic signalling in lymphocytes. Biochim Biophys Acta 2010;1797:1251-1259.

373 Testai L, Barrese V, Soldovieri MV, Ambrosino P, Martelli A, Vinciguerra I, Miceli F, Greenwood IA, Curtis MJ, Breschi MC, Sisalli MJ, Scorziello A, Canduela MJ, Grandes P, Calderone V, Taglialatela M: Expression and function of Kv7.4 channels in rat cardiac mitochondria: possible targets for cardioprotection. Cardiovasc Res 2016;110:40-50.

374 Foster DB, Ho AS, Rucker J, Garlid AO, Chen L, Sidor A, Garlid KD, O’Rourke B: Mitochondrial ROMK channel is a molecular component of mitoK(ATP). Circ Res 2012;111:446-454.

375 Feng S, Li H, Tai Y, Huang J, Su Y, Abramowitz J, Zhu MX, Birnbaumer L, Wang Y: Canonical transient receptor potential 3 channels regulate mitochondrial calcium uptake. Proc Natl Acad Sci U S A 2013;110:11011-11016. 


\section{Cellular Physiology Cell Physiol Biochem 2019;53(S1):11-43

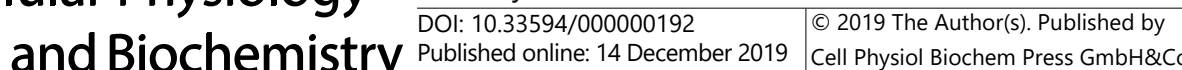

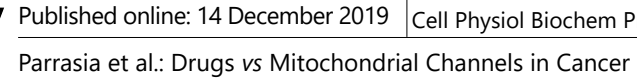

376 Chang HH, Cheng YC, Tsai WC, Tsao MJ, Chen Y: Pyr3 Induces Apoptosis and Inhibits Migration in Human Glioblastoma Cells. Cell Physiol Biochem 2018;48:1694-1702.

377 Gergalova G, Lykhmus 0, Kalashnyk O, Koval L, Chernyshov V, Kryukova E, Tsetlin V, Komisarenko S, Skok M: Mitochondria express alpha7 nicotinic acetylcholine receptors to regulate $\mathrm{Ca} 2+$ accumulation and cytochrome c release: study on isolated mitochondria. PLoS One 2012;7:e31361.

378 Jones IW, Barik J, O’Neill MJ, Wonnacott S: Alpha bungarotoxin-1.4 nm gold: a novel conjugate for visualising the precise subcellular distribution of alpha $7 *$ nicotinic acetylcholine receptors. J Neurosci Methods 2004;134:65-74.

379 Kalashnyk OM, Gergalova GL, Komisarenko SV, Skok MV: Intracellular localization of nicotinic acetylcholine receptors in human cell lines. Life Sci 2012;91:1033-1037.

380 Chernyavsky AI, Shchepotin IB, Galitovkiy V, Grando SA: Mechanisms of tumor-promoting activities of nicotine in lung cancer: synergistic effects of cell membrane and mitochondrial nicotinic acetylcholine receptors. BMC Cancer 2015;15:152.

381 Chernyavsky AI, Shchepotin IB, Grando SA: Mechanisms of growth-promoting and tumor-protecting effects of epithelial nicotinic acetylcholine receptors. Int Immunopharmacol 2015;29:36-44.

382 Wang YZ, Zeng WZ, Xiao X, Huang Y, Song XL, Yu Z, Tang D, Dong XP, Zhu MX, Xu TL: Intracellular ASIC1a regulates mitochondrial permeability transition-dependent neuronal death. Cell Death Differ 2013;20:1359-1369.

383 Sorgato MC, Keller BU, Stuhmer W: Patch-clamping of the inner mitochondrial membrane reveals a voltagedependent ion channel. Nature 1987;330:498-500.

384 Ponnalagu D, Singh H: Anion Channels of Mitochondria. Handb Exp Pharmacol 2017;240:71-101.

385 Singh H, Ashley RH: CLIC4 (p64H1) and its putative transmembrane domain form poorly selective, redoxregulated ion channels. Mol Membr Biol 2007;24:41-52.

386 Zhong J, Kong X, Zhang H, Yu C, Xu Y, Kang J, Yu H, Yi H, Yang X, Sun L: Inhibition of CLIC4 enhances autophagy and triggers mitochondrial and ER stress-induced apoptosis in human glioma U251 cells under starvation. PLoS One 2012;7:e39378. 